UNIVERSIDADE DE BRASÍLIA - UNB

INSTITUTO DE GEOCIÊNCIAS - IG

PÓS-GRADUAÇÃO EM GEOLOGIA

\title{
ANÁLISE INTEGRADA DE DADOS AEROGEOFÍSICOS E GEOLÓGICOS PARA A CARACTERIZAÇÃO DA FAIXA ALTO GUAPORÉ, PORÇÃO SUDESTE DE RONDÔNIA
}

\author{
Carlos Eduardo Santos de Oliveira \\ Dissertação de Mestrado no 352
}

Orientadora: Profa. Dra. Adalene Moreira Silva

Co-orientador: Dr. Jaime Estevão Scandolara

BRASÍLIA - DF 
ANÁLISE INTEGRADA DE DADOS AEROGEOFÍSICOS E GEOLÓGICOS PARA A CARACTERIZAÇÃO DA FAIXA ALTO GUAPORÉ, PORÇÃO SUDESTE DE RONDÔNIA

DisseRTAÇÃO DE MESTRADO № 352

\begin{abstract}
Dissertação de Mestrado elaborada junto ao curso de Pós-graduação em Geologia (Área de concentração em Prospecção e Geologia Econômica), Instituto de Geociências, Universidade de Brasília, como requisito parcial para obtenção do titulo de Mestre em Geologia.
\end{abstract}

Orientadora: Profa. Dra. Adalene Moreira Silva

Co-orientador: Dr. Jaime Estevão Scandolara

\author{
Banca Examinadora: \\ Profa. Dra. Adalene Moreira Silva (Presidente) \\ Prof. Dr. Reinhardt Adolfo Fuck (IG-UnB) \\ Dr. Gilmar José Rizzotto (CPRM-GO)
}

BRASÍLIA - DF

2015 
FICHA CATALOGRÁFICA

Oliveira, Carlos Eduardo Santos

O482a

Análise integrada de dados aerogeofísicos e geológicos para caracterização da Faixa Alto Guaporé, porção sudeste de Rondônia. / Carlos Eduardo Santos Oliveira. - Brasília, 2015.

$75 f$.

Dissertação (Mestrado em Geologia) - Instituto de Geociências, Universidade de Brasília, Brasília, 2015.

Orientadora: Prof ${ }^{a}$. Dr ${ }^{\mathrm{a}}$. Adalene Moreira Silva 


\section{AGRADECIMENTOS}

Este trabalho constitui uma realização pessoal há muito tempo desejada, e desta forma gostaria de agradecer a todas as pessoas que de alguma forma participaram para a concretização desta dissertação.

Aos meus pais e minha irmã, que sempre deram apoio incondicional aos meus estudos e sempre ter mantido o espirito de união que permeia nossa família. A minha esposa e filhas, por terem suportado a minha ausência parcial durante esse período, pela compreensão nos momentos críticos e que muito me estimularam a superar as mais difíceis situações.

Agradeço a Família Gemeli-Scandolara, Zilda, Lucas, Daniel e Otto, por terem me aceitado em seu convívio e ter me acolhido em sua casa por um período considerável o qual sem este apoio dificilmente eu teria conseguido realizar este trabalho.

À minha orientadora, Profa. Dra. Adalene Moreira Silva, agradeço sua paciência, suas ricas sugestões a este trabalho, seu constante estímulo na busca do conhecimento e o apoio recebido ao longo deste processo de formação acadêmica. É uma honra ser seu orientando.

Ao meu co-orientador, Dr. Jaime Estevão Scandolara, um grande amigo e um dos melhores geólogos com quem tive o prazer de aprender um pouco da geologia do estado de Rondônia. Pelo seu apoio, paciência e solicitude em todas as fases desta dissertação.

Ao Serviço Geológico do Brasil - CPRM, como instituição. Ao chefe da residência de Porto Velho, Edgar Iza e Asspro-DGM Cassiano Castro.

Aos amigos da CPRM - Anderson Alves de Souza, Marcos Luiz Quadros, Francisco Reis, Ardiles Gimax, Daiane Hammes, Luiz Palmeira, Manoel Augusto, Rommel Souza, Amílcar Adamy, Terezinha Foro, Luiz Rogério, Maria Rosalva Campos Coelho, Pamela Emanuelle, Gilmar Rizzotto, Angeval Brito, Roberto Gusmão, Raphael Texeira e Marcus Chiarini.

Em especial, aos colegas Bianca Takenaka, Elias Guerra e Guilherme Ferreira por apoio especial e imensas discussões acerca do bloco Sudeste de Rondônia. 
"A única vitória que perdura é a que se conquista sobre a própria ignorância." Jigoro Kano 


\section{SUMARIO}

\section{Sumário}

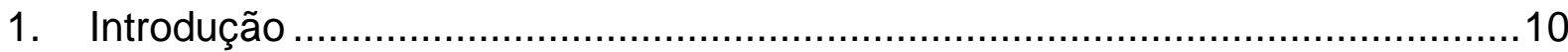

1.1. Apresentação e Justificativas ...............................................................11

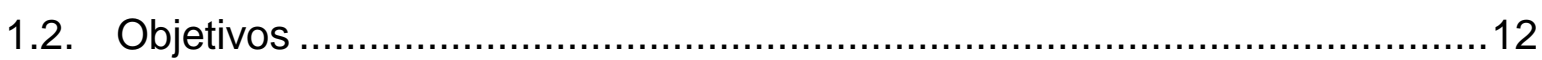

1.3. Localização e Vias de Acesso .................................................................12

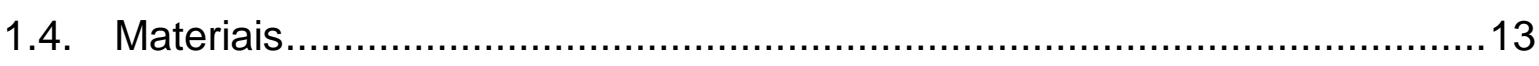

1.4.1. Dados Aerogeofísicos...............................................................13

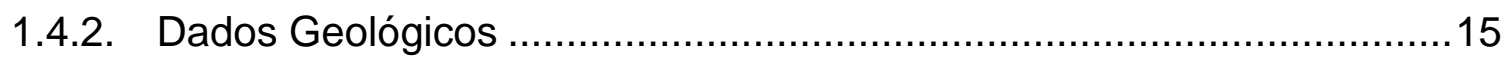

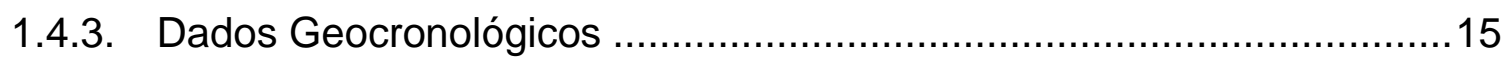

1.5. Estrutura da Dissertação ......................................................................15

2. Cráton Amazônico ....................................................................................

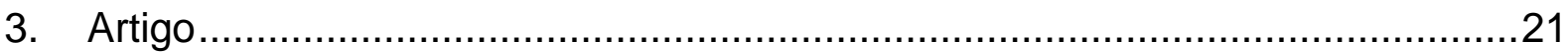

Integrated analysis of airborne geophysical, geological and geochronological data of the Alto Guaporé Belt, Southwestern Amazonian Craton ............................................22

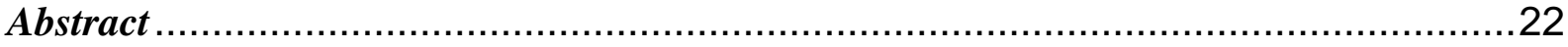

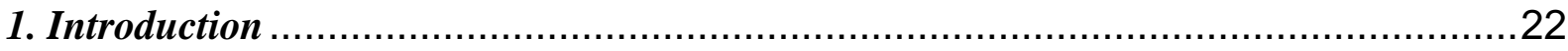

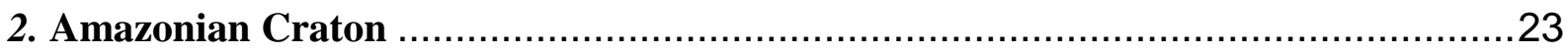

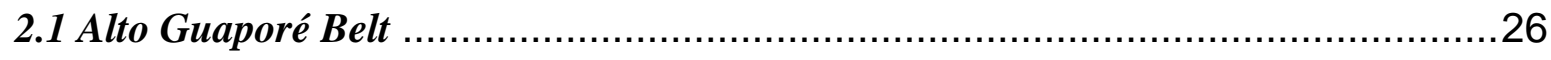

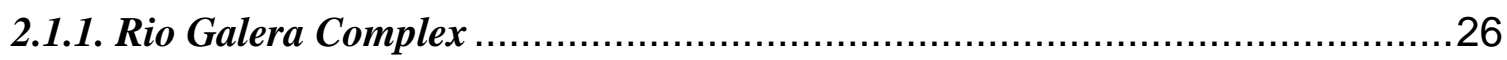

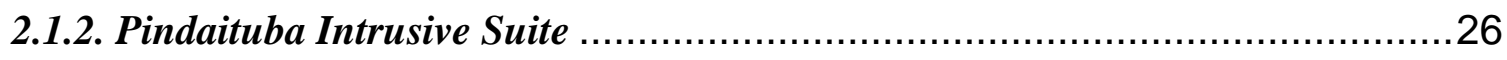

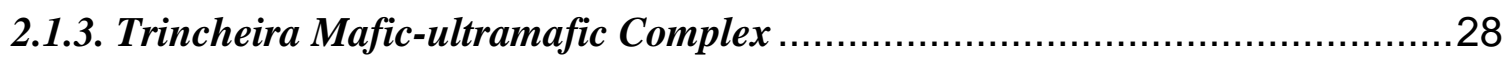

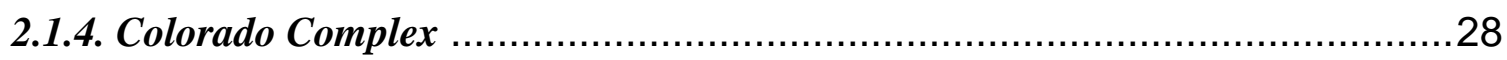

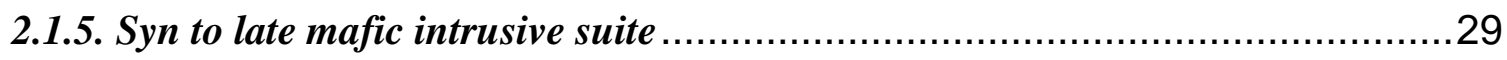

2.1.6. Syn-to late tectonic intrusive granites ........................................................

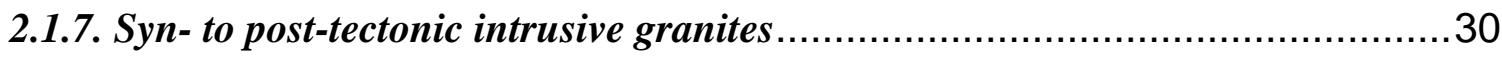

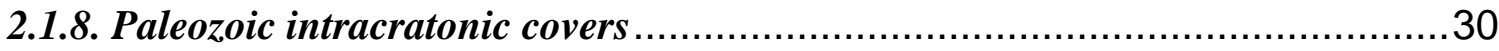

2.1.9. Undifferentiated sedimentary covers ...................................................... 


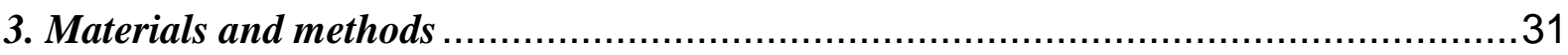

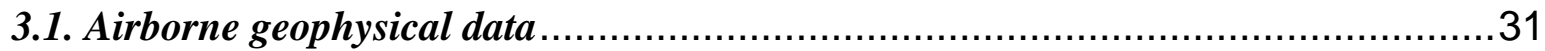

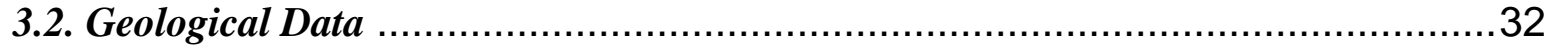

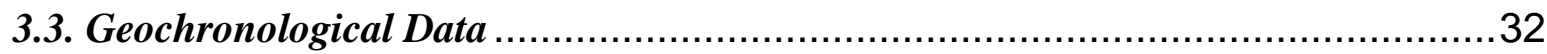

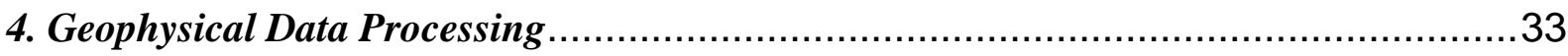

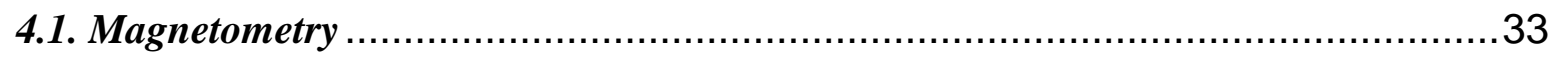

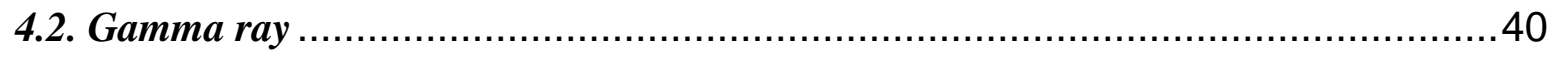

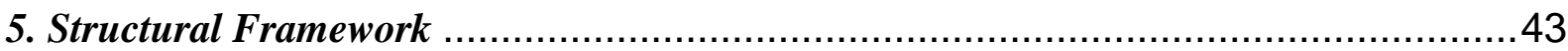

6. Lithologic-Geophysics Association ............................................................ 47

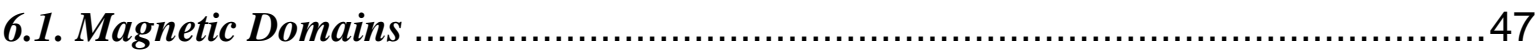

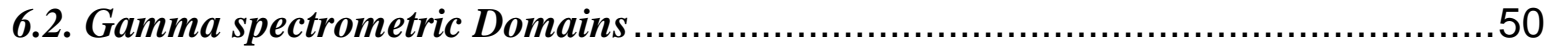

7. Isotopic and geochronological data of igneous rocks of the Alto Guaporé Belt and

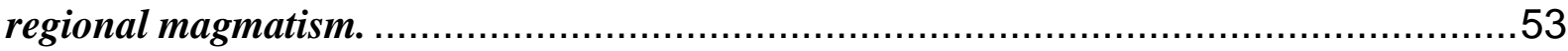

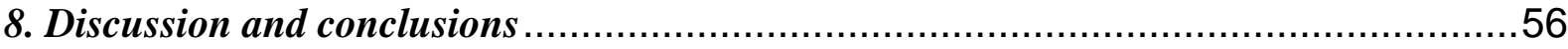

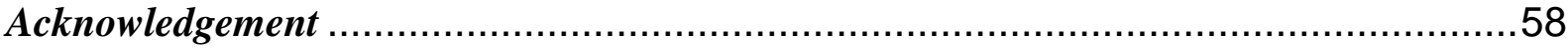

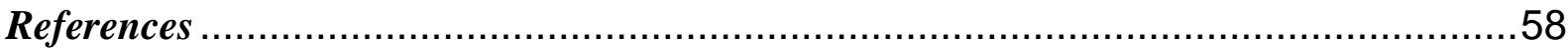

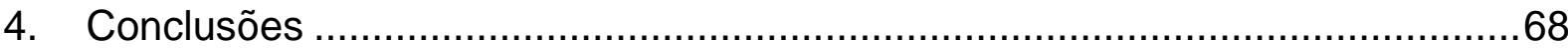

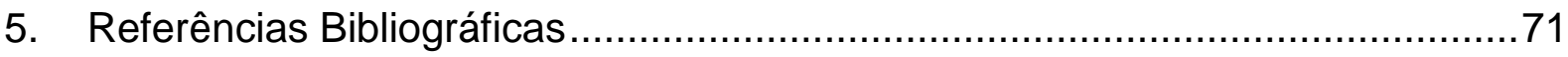




\section{ÍNDICE DE FIGURAS}

Figura 1-1 - Modelo digital de elevação do estado de Rondônia gerado a partir de dados SRTM (Shuttle Radar Topographic Mission), indicando a localização do Aerolevantamento Sudeste de Rondônia (CPRM, 2006), da área de estudo, principais vias de acesso e municípios. Observar que a área do aerolevantamento localiza-se, no sudeste de Rondônia e setor noroeste do estado do Mato Grosso. Na região próxima da fronteira Brasil/Bolívia é mantido um gap de 10 quilômetros de margem da fronteira no aerolevantamento.

Figura 2-1 - Províncias geocronológicas e geotectônicas do Cráton Amazônico. Modelos comparativos a partir da evolução dos trabalhos de Teixeira et al. 1989; Tassinari \& Macambira (1999) e Scandolara et al. 1999; e Santos et al. $(2000,2008)$.

Figura 2-2 - A - Mapa geológico simplificado do sudoeste do Cráton Amazônico mostrando as unidades litoestratigráficas e os limites aproximados dos principais terrenos, cinturões e faixas móveis (adaptado de Schobbenhaus, 2001, onde os limites do Cinturão Alto Guaporé e a zona de sutura do Guaporé foi definido pelo autores Rizzotto et al., 2013). A figura B mostra a subdivisão das seis províncias geocronológicas segundo a concepção de Tassinari et al.(1996) e Tassinari \& Macambira (1999). O polígono em vermelho indica a localização da área de trabalho dentro da denominada Província Rondoniano-San Ignacio, limites da Faixa Alto Guaporé com Terreno Jauru 20 


\title{
RESUMO
}

\section{ANÁLISE INTEGRADA DE DADOS AEROGEOFÍSICOS E GEOLÓGICOS PARA A CARACTERIZAÇÃO DA FAIXA ALTO GUAPORÉ, PORÇÃO SUDESTE DE RONDÔNIA}

\begin{abstract}
A Faixa Alto Guaporé, porção sudeste do estado de Rondônia, constitui um segmento crustal de grande importância para o entendimento da evolução geodinâmica mesoproterozóica do SW do Cráton Amazônico. A faixa possui direção WNW-ESSE, com limites pouco conhecidos e encobertos por sedimentos Fanerozóicos da bacia do Guaporé ao sul e da bacia dos Parecis ao norte. A faixa é constituída pelo Complexo Máfico-ultramáfico Trincheira e pela sequência metassedimentar do Complexo Colorado, que compreendem as rochas de alto grau metamórfico da Faixa Alto Guaporé. Nesta região, durante a fase colisional da evolução da faixa, são intrudidos diversos corpos gabroicos e graníticos em caráter sin-tectônico. Dados aerogeofísicos de alta densidade de amostragem foram utilizados como ferramenta na busca de parâmetros para a interpretação do arcabouço estrutural com base em produtos derivados da magnetometria e dos litotipos associados por meio da gamaespectrometria. A interpretação integrada desses dados contribui para a cartografia geológica e a pesquisa mineral principalmente em terrenos tropicais com escassez de afloramentos. Neste caso, a análise dos dados magnéticos permitiu a individualização de segmentos crustais com assinaturas magnéticas distintas, auxiliando o entendimento tectônico da região. Produtos derivados do campo magnético anômalo, como derivadas horizontais e vertical, bem como a amplitude do sinal analítico, foram utilizados para o mapeamento de domínios magnéticos e estruturais. Observa-se três conjuntos que posteriormente integrados com dados geológicos, permitem mapear três padrões de deformação. Para interpretação de estruturas profundas foram concebidos os mapas de continuação ascendente e da pseudogravidade, e estes comparados com mapa gravimétrico gerado a partir de dados do satélite TOPEX. A integração dos dados radiométricos permitiu elaborar o mapa de domínios gamaespectrométricos, o que tornou possível detalhamento das rochas do embasamento. Os dados geológicos e isotópicos de Sm-Nd permitem inferir a respeito da evolução geodinâmica desta porção do Cráton Amazônico e sugerem um mesmo padrão de evolução crustal para a Faixa Alto Guaporé.
\end{abstract}

Palavras chave: Cráton Amazônico, Faixa Alto Guaporé, Aerogeofísica. 


\section{ABSTRACT \\ INTEGRATED AIRBORNE GEOPHYSICAL AND GEOLOGICAL DATA TO \\ CHARACTERIZE THE ALTO GUAPORÉ BELT, SOUTHEASTERN RONDONIA, BRAZIL}

The Alto Guaporé Belt, southeastern portion of Rondonia state (Brazil), is an important crustal segment for the understanding of the evolution of Proterozoic geodynamics, in the SW of the Amazonian Craton. The Alto Guaporé Belt is a WNWESSE trending area where boundaries are poorly known, and covered up by Phanerozoic sediments of the Guaporé basin on the south and the Parecis Basin on the north. The belt is composed of the mafic-ultramafic Trincheira Complex and the metasedimentary sequences of the Colorado Complex, which configure the regional high-grade metamorphic basement of the Alto Guaporé Belt. In this region, during the collisional phase, several gabbroic and granitic bodies intruded in the syn-tectonic stage. Airborne geophysical data were used as support in the research for paramaters to interpret the structural framework, based on products from the magnetometry and gamma spectrometry. The integrated interpretation of these data contributes to the geological mapping and exploration in tropical environments with few outcrops. Analysis of magnetic data allowed the individualization of crustal segments with different magnetic signatures, improving the understanding of tectonics in this area. Products from total magnetic intensity (TMI), such as the horizontal and vertical derivatives and the analytic signal, were used for mapping magnetic and structural domains. Three major structural domains were observed, which subsequently integrated with geological data, allowed mapping three deformation patterns. For deep structures, were designed the upward continuation maps and pseudo-gravity model and compared with the gravimetric map from TOPEX satellite data. The integration of radiometric data resulted in a map of gamma-spectrometric domains, which aided mapping the basement rock types. Geological and isotopic data Sm- Nd mark the geodynamic evolution of this portion of the Amazonian Craton and suggest the same pattern of crustal evolution for the Alto Guaporé Belt.

Key Words: Amazonian Craton, Alto Guaporé Belt, Airbone Geophysics. 
1. INTRODUÇÃO 


\section{INTRODUÇÃO}

\subsection{APRESENTAÇÃO E JUSTIFICATIVAS}

O Cráton Amazônico é uma das maiores e menos conhecidas áreas do PréCambriano no mundo e uma das principais unidades tectônicas da América do Sul (Scandolara, 2006; Bettencourt et al., 2010). A Faixa Alto Guaporé, localizada na porção sudeste do estado de Rondônia, sudoeste do Cráton Amazônico, representa uma região com amplo potencial econômico-mineral. Apesar de poucos trabalhos desenvolvidos e conhecimento geológico e metalogenético ainda incipiente, existem diversos tipos de depósitos minerais nesta região, a exemplo do garimpo do Zé Goiano (Au, Rizzotto, 2010), Complexo Serra Céu Azul (Cu-Ni e EGP's, Romanini, 1997, 2000), Morro do Leme e Morro Sem Boné (Ni-Cu-Co + EGP's, Nunes, 2000).

Ao longo das últimas décadas, destacam-se alguns estudos regionais na porção sudoeste do Cráton Amazônico como: o reconhecimento geológico do escudo Pré-Cambriano boliviano (Litherland et al., 1986); integração de dados geocronológicos no Cráton Amazônico (Santos et al. 2000); a evolução da porção central do centro-leste de Rondônia (Scandolara, 2006); a evolução geológica na região que engloba a região do Brasil-Bolívia-Mato Grosso (Ruiz, 2005); evolução tectônica da margem austral do Cráton Amazônico no Mesoproterozoico (Rizzotto, 2012), além das relevantes revisões de Bettencourt et al. (2010) e Texeira et al., 2010.

As principais adversidades encontradas no estudo de regiões similares e na reconstrução de sua história evolutiva estão relacionadas com a obliteração das relações estratigráficas originais, que são intensificadas em função da ausência de afloramentos contínuos, que dificultam a confecção de mapas geológicos. O espesso manto de intemperismo e o grau de alteração das rochas nessas regiões obscurecem as relações entre as diferentes unidades tectono-estratigráficas.

A utilização de dados aerogeofísicos fornece subsídios na busca de parâmetros para a interpretação do arcabouço estrutural com base em produtos derivados de dados magnéticos e gamaespectrométricos. A interpretação integrada desses dados contribui para a cartografia geológica e a exploração mineral, principalmente em terrenos tropicais com escassez de afloramentos. A integração de dados aerogeofísicos, geológicos e geoquímicos em ambiente SIG possibilita a 
definição de zonas favoráveis para hospedar mineralizações em escala regional (Jaques et al., 1997; Gunn et al., 1997a,b).

A principal meta deste trabalho é caracterizar os domínios lito-estruturais do sudeste de Rondônia, a partir de produtos derivados de dados magnéticos e gamaespectrométricos aéreos e integração com dados geológicos, estruturais e geocronológicos disponíveis na literatura para contribuir com o entendimento do arcabouço tectônico e mineralizações associadas.

\subsection{OBJETIVOS}

O objetivo central deste projeto é efetuar a caracterização geológico-geofísica da Faixa Alto Guaporé, SW do Cráton Amazônico, a partir da integração de dados geológicos, geofísicos e geocronológicos, visando compreender as estruturas geológicas e os ambientes tectônicos nos quais a faixa se formou.

Os objetivos específicos incluem:

- Mapear estruturas regionais e locais por meio da investigação de dados aeromagnéticos;

- Caracterizar os diferentes domínios geológicos com base a interpretação dos diferentes produtos derivados de dados magnéticos e gamaespectrométricos, e integrá-los com dados isotópicos disponíveis na literatura, com intuito de ampliar o conhecimento tectônico da área de estudo.

\subsection{LOCALIZAÇÃO E VIAS DE ACESSO}

A área de pesquisa está localizada na porção sudeste do estado de Rondônia, abrangendo uma área de $15.061 \mathrm{~km}^{2}$, a qual engloba um conjunto de cinco folhas na escala 1:100.000, que abrangem os municípios de Colorado d'Oeste, Cerejeiras, Pimenteiras d'Oeste, Cabixi, Corumbiara e Chupinguaia (Figura 1-1). 


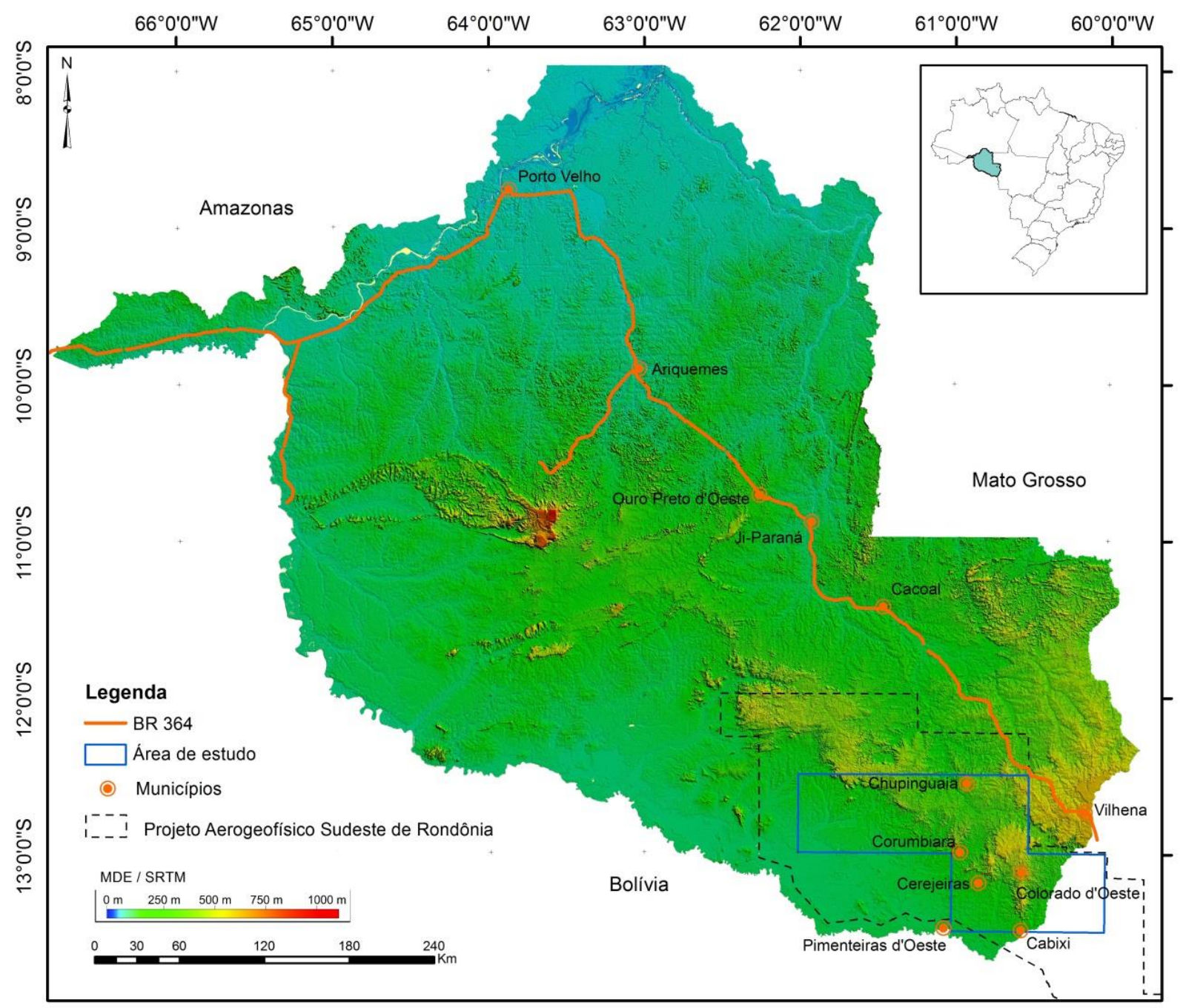

Figura 1-1 - Modelo digital de elevação do estado de Rondônia gerado a partir de dados SRTM (Shuttle Radar Topographic Mission), indicando a localização do Aerolevantamento Sudeste de Rondônia (CPRM, 2006), da área de estudo, principais vias de acesso e municípios. Observar que a área do aerolevantamento localiza-se, no sudeste de Rondônia e setor noroeste do estado do Mato Grosso. Na região próxima da fronteira Brasil/Bolívia é mantido um gap de 10 quilômetros de margem da fronteira no aerolevantamento.

\subsection{MATERIAIS}

\subsubsection{Dados Aerogeofísicos}

A área de estudo é recoberta pelo levantamento aerogeofísico Sudeste de Rondônia, executado pelo consórcio das empresas LASA Engenharia e Prospecções S.A. e Prospectors Aerolevantamentos e Sistemas LTDA., a serviço da Companhia de Pesquisa de Recursos Minerais/Serviço Geológico do Brasil. O aerolevantamento ocorreu durante os anos de 2005 e 2006, na porção sudeste do Estado de Rondônia e parte do extremo noroeste do Estado do Mato Grosso, recobrindo $93.189,12 \mathrm{~km}$ de perfis aeromagnetométricos $\mathrm{e}$ 
aerogamaespectrométricos de alta densidade de amostragem. $O$ sistema aeromagnético utilizado no aerolevantamento consistiu em um sensor de vapor de césio montado na cauda (tipo stinger) da aeronave, com resolução de $0.001 \mathrm{nT}$. As leituras do magnetômetro foram realizadas a cada 0,1 segundo, o que equivale para a velocidade de $280 \mathrm{~km} / \mathrm{h}$ da aeronave, a aproximadamente 7,8 $\mathrm{m}$ no terreno. Neste aerolevantamento foram utilizadas duas aeronaves, utilizando-se distintos magnetômetros (Geometics G822A e Scintrex CS-2). O sistema gamaespectrométrico Exploranium, modelo GR-820 utilizado mediu o espectro de radiações gama natural discriminando-o em 256 canais espectrais com sistema detector constituído por dois conjuntos de cristais (iodeto de sódio ativado por tálio) voltados para baixo (downward looking) de 1024 polegadas cúbicas cada, (volume total de 2048 polegadas cúbicas) e dois cristais voltados para cima (upward looking), de 256 polegadas cúbicas cada (totalizando 512 polegadas cúbicas (CPRM/LASA Engenharia e Prospecções S/A, 2006). As leituras do gamaespectrômetro foram realizadas a cada 1 segundo, representando medições a intervalos de aproximadamente $78 \mathrm{~m}$ no terreno.

Para os dados radiométricos, para efeito de pré-processamento, foram suprimidos os ruídos e contribuições primárias como, por exemplo, a remoção do background, altura efetiva de voo e a correção do espalhamento de Compton. Finalmente, foi realizada a determinação do coeficiente de Skyshine e a conversão dos dados radiométricos em porcentagem (potássio) e partes por milhão (eTh e eU).

O espaçamento das linhas de voo e de controle é $0,5 \mathrm{~km}$ e 10,0 km, respectivamente, orientados nas direções N-S e E-W. A altura nominal de voo foi fixada em 100 m sobre o terreno. O aerolevantamento Sudeste de Rondônia possui um formato irregular por abranger uma região de fronteira, onde se conserva uma distância de 10 quilômetros da linha divisória Brasil/Bolívia até a extremidade do aerolevantamento (Figura 1-1). Para Isles \& Rankin (2013), formatos singulares de levantamentos com muitos vértices e pequenos segmentos apresentam dificuldade à interpretação, em razão do senso geológico/geométrico interpretativo, tanto de feições parcialmente cobertas como com formato de padrão singulares. 


\subsubsection{Dados Geológicos}

Foram utilizadas como base os mapas de geologia e recursos minerais do Estado de Rondônia de Scandolara et al. (1999), Quadros \& Rizzotto (2007) e os mapas do Projeto Guaporé Folhas Pimenteiras(SD.20-X-D) e Vilhena (SD.20-X-B) (Rizzotto, 2010, e 2014). Foi considerado o mapa de integração geológico-geofísico (Oliveira et al., 2015) como produto interpretativo baseado na extrapolação de informações de dados aeromagnéticos aerogamaespectrométricos.

\subsubsection{Dados Geocronológicos}

Com o propósito de compreender a evolução crustal da Faixa Alto Guaporé foram compilados dados de geoquímica isotópica, $\mathrm{Sm}-\mathrm{Nd}, \mathrm{U}-\mathrm{Pb}$ e $\mathrm{Ar}-\mathrm{Ar}$ de diversos pesquisadores (Ruiz, 2005, Scandolara, 2006; Rizzotto, 2010; Rizzotto et. al., 2013).

\subsection{ESTRUTURA DA DISSERTAÇÃO}

Esta dissertação de mestrado foi desenvolvida no Instituto de Geociências da Universidade de Brasília sob a orientação da Professora Dra. Adalene Moreira Silva e co-orientação do Dr. Jaime Estevão Scandolara e faz parte do projeto "Províncias Metalogenéticas do Brasil - Áreas Rondônia e Acre - Bloco Sudeste", um projeto de pesquisa do Serviço Geológico do Brasil.

Esta dissertação está estruturada em três partes principais. A primeira apresenta a introdução às ideias e justificativas para o desenvolvimento da pesquisa bem como objetivos, materiais, localização da área de pesquisa. A segunda parte está organizada em formato de artigo, em língua inglesa, submetido à revista Precambrian Research, e intitula-se "Integrated airborne geophysical, geological and geochronological data of the Alto Guaporé Belt, Southwestern Amazonian Craton". $\mathrm{Na}$ terceira parte encontram-se as discussões e conclusões sobre os resultados obtidos 
2.CrÁton AmaZÔNICO 


\section{CRÁTON AMAZÔNICO}

O Cráton Amazônico, uma das maiores e menos conhecidas áreas précambrianas do mundo, inclui-se entre as principais unidades tectônicas da América do Sul $\left(5.600 .000 \mathrm{~km}^{2}\right)$, separado da faixa orogênica andina por extensiva cobertura Cenozoica (Llanos colombianos e venezuelanos, Chaco paraguaio-boliviano, etc.), que dificulta o estabelecimento de seu limite ocidental. Sua extensão para oeste, por sob a cobertura Cenozoica, é sugerida pela presença de fragmentos mesoproterozóicos na Cordilheira Oriental, como Garzón e Santa Marta (Kroonenberg,1982; Priem et al.,1989). No Brasil o Cráton Amazônico, com área aproximada de $4.400 .000 \mathrm{~km}^{2}$, é limitado a leste pelo Grupo Baixo Araguaia, a sul e sudeste pelos grupos Alto Paraguai, Cuiabá e Corumbá e por rochas geradas durante o Ciclo Orogênico Brasiliano (900-540 Ma, Pimentel \& Fuck, 1992). É em relação às rochas geradas durante esse ciclo orogênico que o conceito de cráton é aplicado, representando a área estabilizada em tempos pré-brasilianos (cerca de $1000 \mathrm{Ma}$ ). O cráton é coberto por bacias fanerozóicas a leste (Parnaíba), sul (Xingu e Alto Tapajós), sudoeste (Parecis), oeste (Solimões), norte (Tacutu) e centro (Amazonas). A bacia fanerozoica Amazônica divide o cráton em dois grandes blocos: o escudo das Guianas, no norte, e o escudo Brasil Central, ao sul.

A porção sudoeste do Cráton Amazônico, região alvo desta pesquisa, contém o registro de evolução geotectônica policíclica com embasamento formado a partir de $1.82 \mathrm{Ga}$ e resultante de sucessivos episódios de magmatismo, metamorfismo e sedimentação e deformação que o afetaram (Scandolara, 1999). Três províncias geocronológicas (sensu Cordani et al., 1979; Litherland et al., 1986; Teixeira et al., 1989; Tassinari \& Macambira, 1999) constituem o arcabouço geotectônico do SW do Cráton Amazônico (Figura 2-1a): Província Rio Negro-Juruena (1800-1550 Ma), Província Rondoniana-San Ignacio (1450-1250 Ma) e Província Sunsás (1300-1000 $\mathrm{Ma}$ ). De conotações mobilistas, o modelo é baseado principalmente em dados isotópicos $\mathrm{Rb}-\mathrm{Sr}$, método com limitações bem conhecidas em áreas polideformadas, polimetamorfisadas, ou de alto grau metamórfico, onde o sistema pode ser facilmente reaberto. As províncias geocronológicas receberam conotações tectônicas, segundo modelo dinâmico do tipo mobile belts (Cordani \& Brito Neves, 1982; Litherland et al., 1986; Teixeira et al., 1989; Tassinari, 1981; Tassinari et al., 1984, 1996, 2000). Para estes autores os mobile belts teriam se desenvolvido de 
forma paralela durante o Mesoproterozóico, a partir de núcleo mais antigo, a Província Amazônia Central, com idades progressivamente mais jovens no sentido SW do Cráton. Novos dados geocronológicos (U-Pb convencional, LA-ICP-MS e SHRIMP), reinterpretação de valores isotópicos Sm-Nd e inclusão de informações retiradas de levantamentos de campo, conduziram a novo entendimento sobre a subdivisão e evolução do Cráton Amazônico no Pré-Cambriano, com a definição de sete províncias geológicas (Santos et al., 2000). Segundo estes autores, o SW do Cráton Amazônico é constituído por apenas duas províncias geológicas: RondôniaJuruena (1810-1520 Ma, orogênese Ouro Preto) e Sunsás (1450-990 Ma, orogêneses Candeias e Nova Brasilândia), construídas por eventos acrescionário/colisional e colisional, respectivamente (Figura 2-1b).
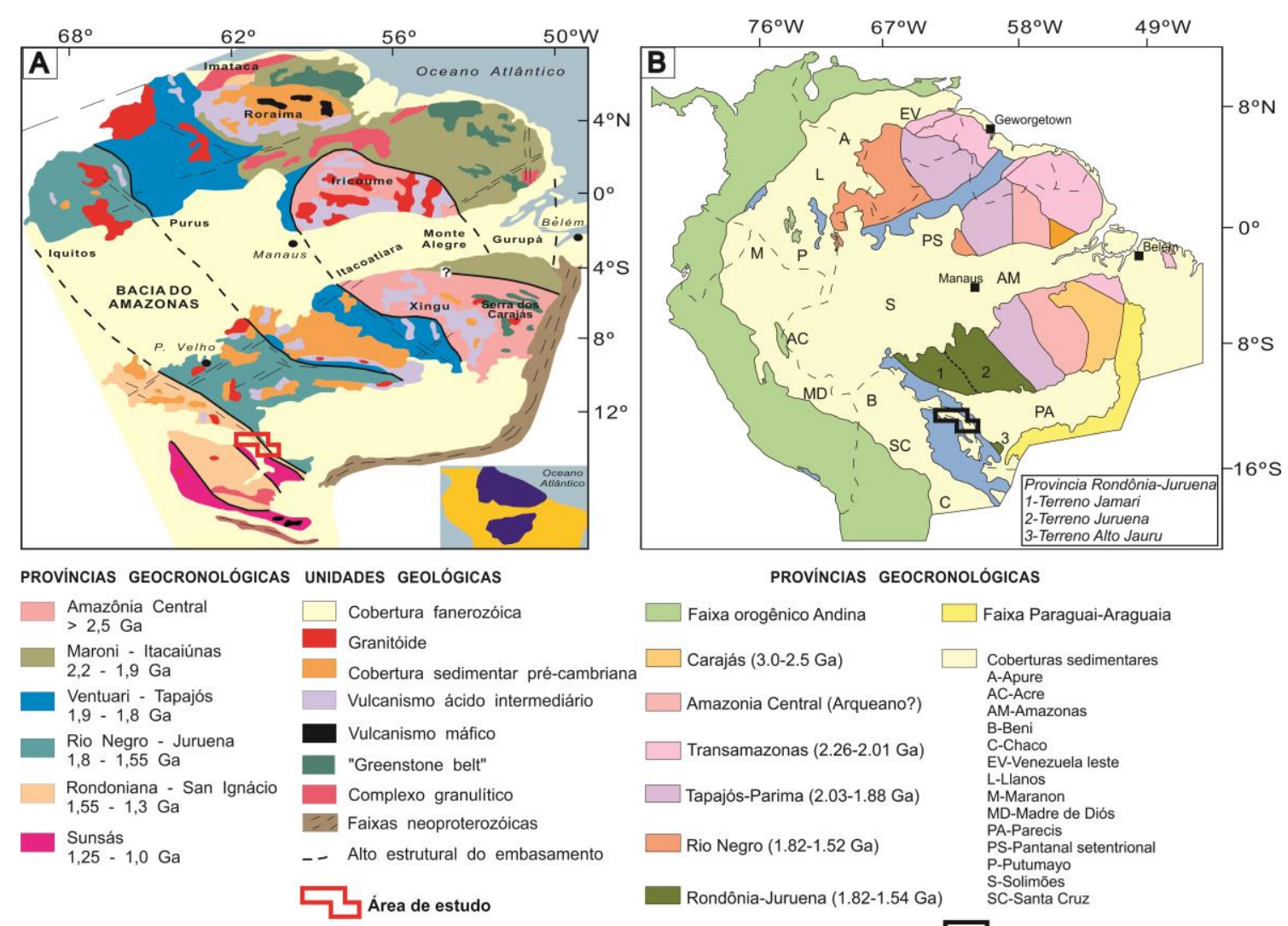

PROVINCIAS GEOCRONOLÓGICAS

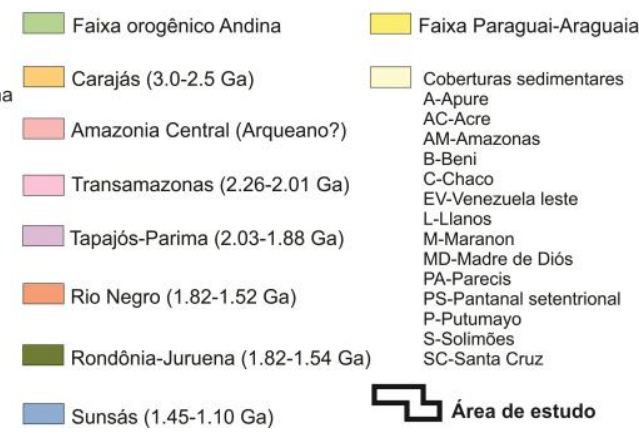

Figura 2-1 - Províncias geocronológicas e geotectônicas do Cráton Amazônico. Modelos comparativos a partir da evolução dos trabalhos de Teixeira et al. 1989; Tassinari \& Macambira (1999) e Scandolara et al. 1999; e Santos et al. (2000, 2008).

O termo Rondoniano-San Ignácio foi introduzido por Cordani et al. (1979) para designar um evento metamórfico deformacional no sudoeste do Cráton Amazônico. Posteriormente, Teixeira \& Tassinari (1984) e Teixeira et al.,(1989) interpretaram a província como cinturão móvel do norte de Rondônia até a região de San Ignácio, na 
Bolívia. O termo Província Rondoniano San Ignácio foi proposto utilizando datações U-Pb e idades SHRIMP (Tassinari et al. 1996; Tassinari et al., 2000), para a subdivisão da Província em: Terreno Rio Alegre (1,50 Ga), Orógeno Santa Helena (1,47 - 1,42 Ga) e Orógeno Rondoniano San-Ignácio (1,40 - 1,29 Ga). Bettencourt et al. (2010), em revisão da Província Rondoniano-San Ignácio, destacam as principais orogenias e o arranjo tectônico desta região, separando em três terrenos e acrescentando o cinturão Alto Guaporé (Figura 2-2). Assim, a Província RondonianoSan Ignácio, por definição inclui: (1) Terreno Jauru (1,78 - 1,42 Ga); (2) Terreno Paraguá (1,74 - 1,32 Ga); (3) Terreno Rio Alegre (1,51 - 1,38 Ga) e (4) Faixa Alto Guaporé $(1,42-1,34 \mathrm{Ga})$.

A Faixa Alto Guaporé localizada na porção sudeste de Rondônia, possui estruturação WNW-ESSE. O limite norte é coberto por rochas sedimentares Fanerozóicas da Bacia dos Parecis e a extremidade sul é pobremente conhecida e coberta por sedimentos Cenozoicos da bacia hidrográfica do Guaporé, restringindo a área de embasamento exposto à uma faixa reduzida de aproximadamente $4.000 \mathrm{~km}^{2}$ (Figura 2-2). Rizzotto \& Dehler (2007) denominaram a Faixa Móvel Alto Guaporé e interpretaram-na como sendo derivada de uma orogenia acrescionária-colisional, em condições de médio a alto grau metamórfico. A faixa tem idade compatível com a da orogenia San-lgnácio, no leste da Bolívia (Litherland et al. 1986). A Faixa Alto Guaporé é representada principalmente por rochas máfico-ultramáficas do Complexo Trincheira (Romanini, 2000; Rizzotto e Hartaman, 2012) e rochas metassedimentares do Complexo Colorado (Rizzotto et al., 2002). Em acréscimo são intrudidos, em caráter sin-tectônico, diversos plutons gabroicos e graníticos. 


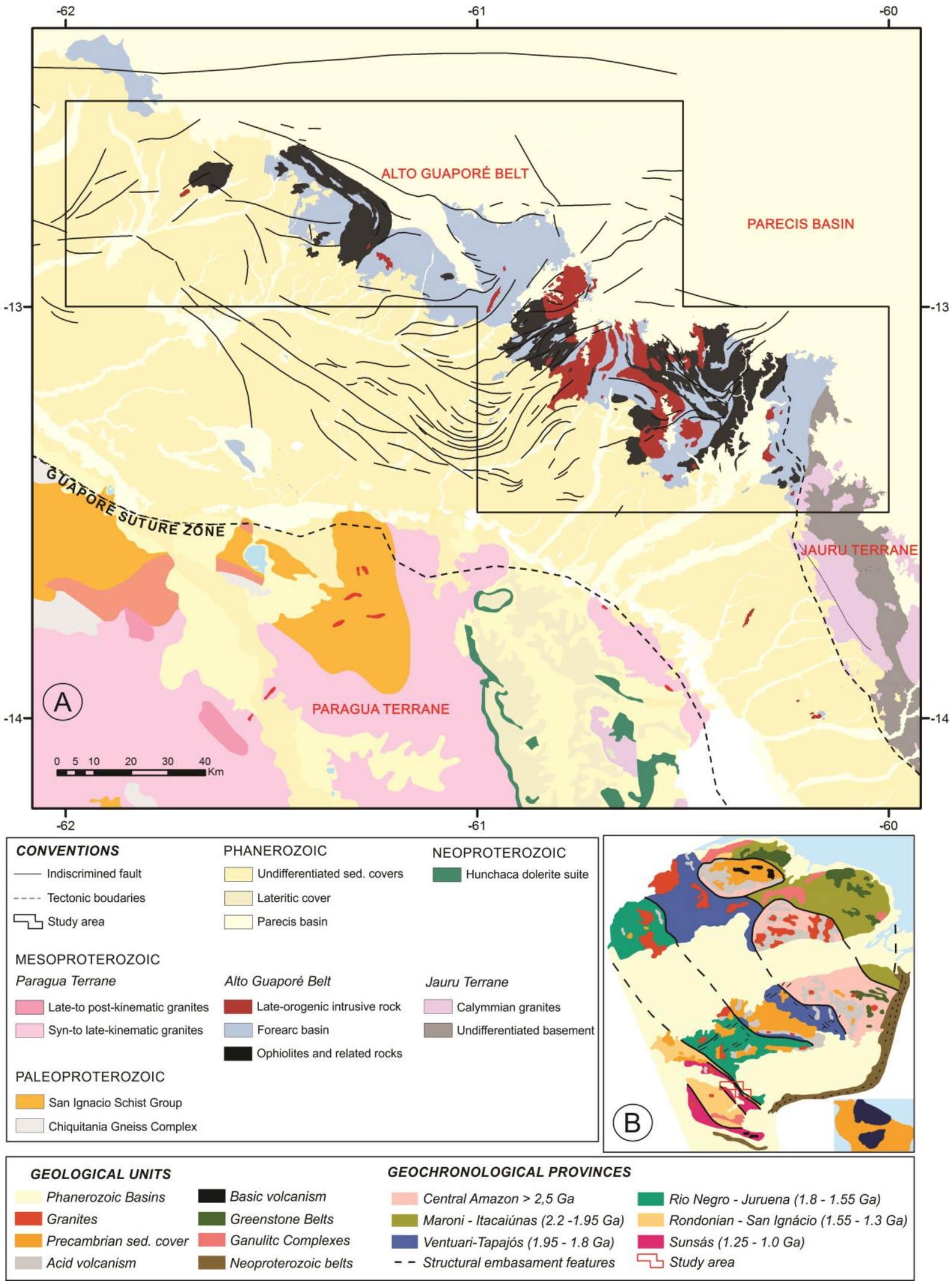

Figura 2-2 - A - Mapa geológico simplificado do sudoeste do Cráton Amazônico mostrando as unidades litoestratigráficas e os limites aproximados dos principais terrenos, cinturões e faixas móveis (adaptado de Schobbenhaus, 2001, onde os limites do Cinturão Alto Guaporé e a zona de sutura do Guaporé foi definido pelo autores Rizzotto et al., 2013). A figura B mostra a subdivisão das seis províncias geocronológicas segundo a concepção de Tassinari et al.(1996) e Tassinari \& Macambira (1999). O polígono em vermelho indica a localização da área de trabalho dentro da denominada Província Rondoniano-San Ignacio, limites da Faixa Alto Guaporé com Terreno Jauru 
3. Artigo 


\section{ARTIGO CIENTÍ́FICO}

\section{Integrated analysis of airborne geophysical, geological and geochronological data of the Alto Guaporé Belt, Southwestern Amazonian Craton}

Carlos Eduardo Santos de Oliveira ${ }^{\mathrm{a}}$, Adalene Moreira Silva ${ }^{\mathrm{b}}$, Jaime Estevão Scandolara ${ }^{\mathrm{a}}$

${ }^{\mathrm{a}}$ Geological Survey of Brazil

${ }^{\mathrm{b}}$ Institute of Geoscience, Universidade de Brasília (UnB)

\section{Abstract}

Using high resolution airborne geophysics integrated with geological, isotopic chemistry and field data improved the geologic interpretation and understanding of the evolution of the SW Amazonian Craton. Aeromagnetic data allowed the generation of products from the total magnetic intensity (TMI, reduced from IGRF), such as the first order derivates and the analytical signal amplitude, which enabled the identification of terrane limits, structural pattern and geometry of magnetic bodies. Integration of these products resulted in qualitative models of magnetic and structural domains which enabled the recognition of three deformation patterns. The pseudo-gravity map enhanced the deep structures and when contrasted with the TOPEX satellite gravimetric map showed a clear discrimination of deep sources between the Alto Guaporé Belt and the Jauru Terrane. This relation is not easily understood when a conventional analysis of magnetic data is performed. The airborne gamma spectrometric data showed areas of concentration and dispersion of radioelements, improving the geologic mapping for the definition of geologic contacts, intrusive bodies and the overlap of areas with sedimentary covers and regolith material. The geological, geochronological U$\mathrm{Pb}$ and isotopic $\mathrm{Sm}-\mathrm{Nd}$ data helped understanding the geodynamic evolution and suggest the same crustal evolution pattern for this portion of the Amazonian craton.

Keywords: Amazonian Craton, Alto Guaporé Belt, Airbone Geophysics, Geochronological data

\section{Introduction}

The southeastern portion of Rondônia State, southwest of the Amazonian Craton, represents an exploratory border with wide economical-mineral potential. Until today, little 
work has been developed in this region and the geological and metallogenetic understanding is scarce. The knowledge of mineral occurrences is limited to different associations, like the gold digging of Zé Goiano, the Serra Céu Azul Complex (Cu-Ni and EGP's) (Romanini, 1997, 2000), Morro do Leme and Morro Sem Boné (Ni-Cu-Co + EGP's) (Nunes, 2000).

In the area, Rizzotto and Hartmann (2012) defined an incomplete ophiolite sequence in the mafic-ultramafic Trincheira Complex, and consequently, the suture zone between the Amazonian protocraton and the Paragua Craton, emphasizing the interest in the mineral potential of the southeastern part of Rondônia. However, great part of the region is covered by Cenozoic sediments of the hydrographic basin of Guaporé on the south, and by Phanerozoic sedimentary rocks of the Parecis Basin on the north, restricting the exposed basement area to a reduced zone of approximately $4,000 \mathrm{~km}^{2}$. In addition, it is important to highlight that the absence of outcrop continuity, wide weathering profile and the level of alteration of rocks overshadow the relationships between the several tectono-stratigraphic units and complicates the systematic geological mapping.

Thus, essay airborne geophysical data supplies support in the search for parameters to aid in the interpretation of the structural framework of the region based on products from magnetometry and gamma spectrometry. The integrated interpretation of these data contributes to the geological mapping and mineral exploration, specially in tropical terranes with few outcrops. Integration of airborne geophysical, geological and geochemical data in SIG enables the definition of favorable zones to host mineralizations in regional scale (Jaques et al., 1997; Gunn et al., 1997a, b).

The application of techniques and procedures to airborne geophysical products contributes with the traditional mapping, which favors the interpretation of geological and structural relations, allowing the regions to be imaged in two or three dimensions and contributing with the generation of minimum exploratory conditions (Milligan and Gunn, 1997; Stewart and Betts, 2010; Metelka et. al., 2011). The main goal of this work is to characterize the litho-structural domains of southeast Rondônia through the analysis and interpretation of aerial magnetometric and gamma-spectrometric data and the combination with geological, structural and geochronological data in order to improve the understanding of the tectonic framework and associated mineralizations.

\section{Amazonian Craton}

The Amazonian Craton, one of the largest and least known Precambrian areas in the world, is one of the main tectonic units of South America $\left(5,600,000 \mathrm{~km}^{2}\right)$, separated from the 
Andean orogenic belt by an extensive Cenozoic cover (Colombian and Venezuelan plains, Paraguayan-Bolivian Chaco, etc), that complicates the definition of its western edge. Its extension to the west, below the Cenozoic cover, is suggested by the presence of Mesoproterozoic fractions in the Eastern Ridge, such as Garzón and Santa Marta (Kroonenberg, 1982; Priem et al., 1989). In Brazil, the Amazonian Craton, with an approximate area of $4,400,000 \mathrm{~km}^{2}$, is bordered on the east by the Baixo Araguaia Group, on the south and southeast by the Alto Paraguai, Cuiabá and Corumbá groups and by rocks originated during the Brasiliano Orogenic Cycle (900-540 Ma, Pimentel and Fuck, 1992). In this case, the concept of craton is applied in relation to the rocks originated during that orogenic cycle, constituting the stabilized area in pre-Brasiliano periods (about 1,000 Ma). The craton is covered by Phanerozoic basins on the east (Parnaíba), south (Xingu and Alto Tapajós), southeast (Parecis), west (Solimões), north (Tacutu) and central area (Amazonas).

The southwestern part of the Amazonian Craton (Fig. 1), which is the target of this work, carries the poly-cyclic geotectonic evolution record with basement originated from 1.82 $\mathrm{Ga}$ and is the result of successive episodes of magmatism, metamorphism, sedimentation and deformation (Scandolara and Amorim, 1999). Three geochronological provinces (Cordani et al., 1979; Litherland et al., 1989; Teixeira et al., 1989; Tassinari and Macambira, 1999) conform the geotectonic framework of the SW of the Amazonian Craton: Rio Negro-Juruena (1800-1550 Ma), Rondonian-San Ignacio (1450-1250 Ma) and Sunsás (1300-1000 Ma). In a mobilist sense, the model is based mainly on isotopic data $\mathrm{Rb}-\mathrm{Sr}$, method with limitations in polydeformed, polymetamorphosed areas, or with a high degree of metamorphism, where the system can be easily reopened. The geochronological provinces acquired tectonic connotations, according to the dynamic model, of mobile belts (Cordani and Brito Neves, 1982; Litherland et al., 1986; Teixeira et al., 1989; Tassinari, 1981; Tassinari et al., 1984, 1996, 2000). For these authors, the mobile belts would develop in parallel during the Mesoproterozoic, from an older core, the Central Amazônia Province, with age progressively younger in a SW direction of the craton. New geochronological data (conventional U-Pb, LAICP-MS and SHRIMP), reinterpretation of isotopic Sm-Nd values and insertion of information coming from field work, led to a new understanding about the subdivision and evolution of the Amazonian Craton in the Precambrian, with the definition of seven geological provinces (Santos et al., 2000). According to them, the SW of the Amazonian Craton consists of only two geological provinces: Rondônia-Juruena (1810-1520 Ma, Ouro Preto orogenesis) and Sunsás (1450-990 Ma, Candeias and Nova Brasilândia orogenesis), built by accretionary/collisional and collisional events respectively. 


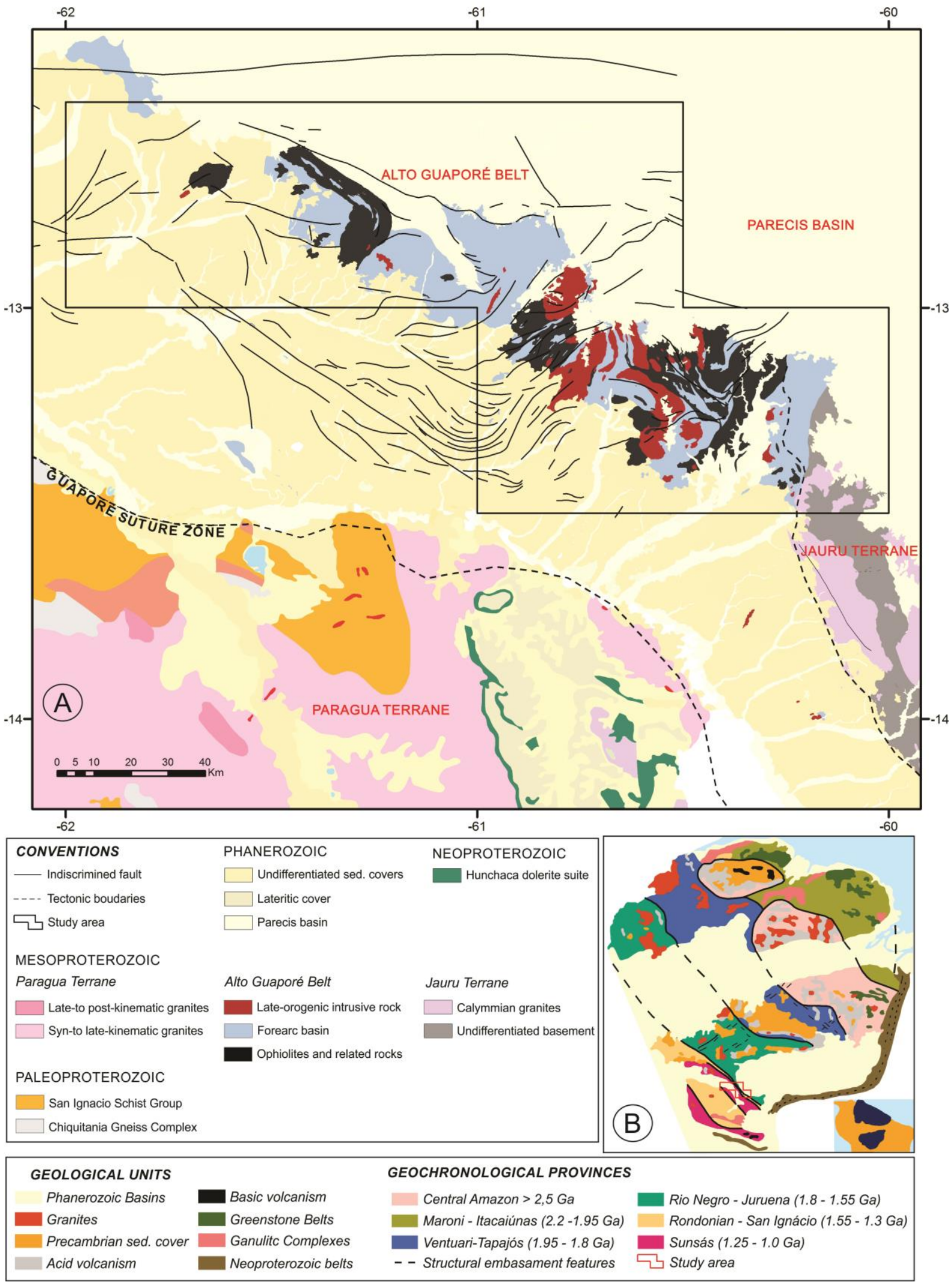

Figure 1- (a) Simplified geological map of the southwest of the Amazonian Craton, with approximate limits of the main terranes, belts and mobile belt (Adapted from Schobbenhaus, 2001; Rizzotto and Hartmann, 2012); and (b) subdivision of the six geochronological provinces according to Tassinari et al. (1996) and Tassinari and Macambira (1999). 


\subsection{Alto Guaporé Belt}

The study area (Fig. 1) is located in the NNW border of the Jauru Terrane (Saes and Fragoso Cesar, 1996) and includes almost all the Alto Guaporé Belt (Rizzotto and Hartmann, 2012), within the Rondonian/San Ignacio Province (Teixeira and Tassinari, 1984; Litherland et al. 1986). The stratigraphic organization of the area under study is based on that presented on the Geological Map of Rondônia (Scandolara et al. 1999; Quadros and Rizzotto, 2007), with adjustments proposed by Rizzotto (2010). In this region, the following units occur (Fig. 2): (1) Rio Galera Complex; (2) Pindaituba Intrusive Suite; (3) Mafic-Ultramafic Trincheira Complex; (4) Colorado Complex; (5) Syn-to late- tectonic mafic and ultramafic bodies; (6) Syn- to late- tectonic granites of the Igarapé Enganado and Cerejeiras Intrusive Suites; (7) Syn- to post- tectonic granites of the Alto Escondido Intrusive Suite; (8) Paleozoic covers of the Corumbiara Formation and the Parecis Group (Utiariti and Rio Ávila Formations); and (9) Cenozoic covers of the Guaporé Formation and associated sedimentary covers.

\subsubsection{Rio Galera Complex}

The Rio Galera Complex consists of biotite-muscovite schists, biotite gneiss, hornblende-biotite gneiss, diopside-hornblende gneiss, sillimanite-quartz schists and hornblende amphibolites. The Ar/Ar ages of $1208,2 \pm 2,5 \mathrm{Ma}$ and $1165 \pm 5,4 \mathrm{Ma}$ in amphibolites can indicate the opening of the system during a superimposed event (Ruiz 2005).

\subsubsection{Pindaituba Intrusive Suite}

Pindaituba represents a set of intrusions whitin the supracrustal and orthogneiss rocks of the Jauru Domain (Ruiz, 2005). The Pindaituba Suite is represented by the Praia Alta and Rio Piolho granites and occurs as elongated batholiths with a $\mathrm{N} 20^{\circ}-40^{\circ} \mathrm{W}$ direction, varying in composition from tonalite to syenogranite. Ruiz (2005) used U-Pb in zircon, through the isotopic dilution technique on these rocks, and determined crystallization ages of $1423 \pm 11$ Ma. 


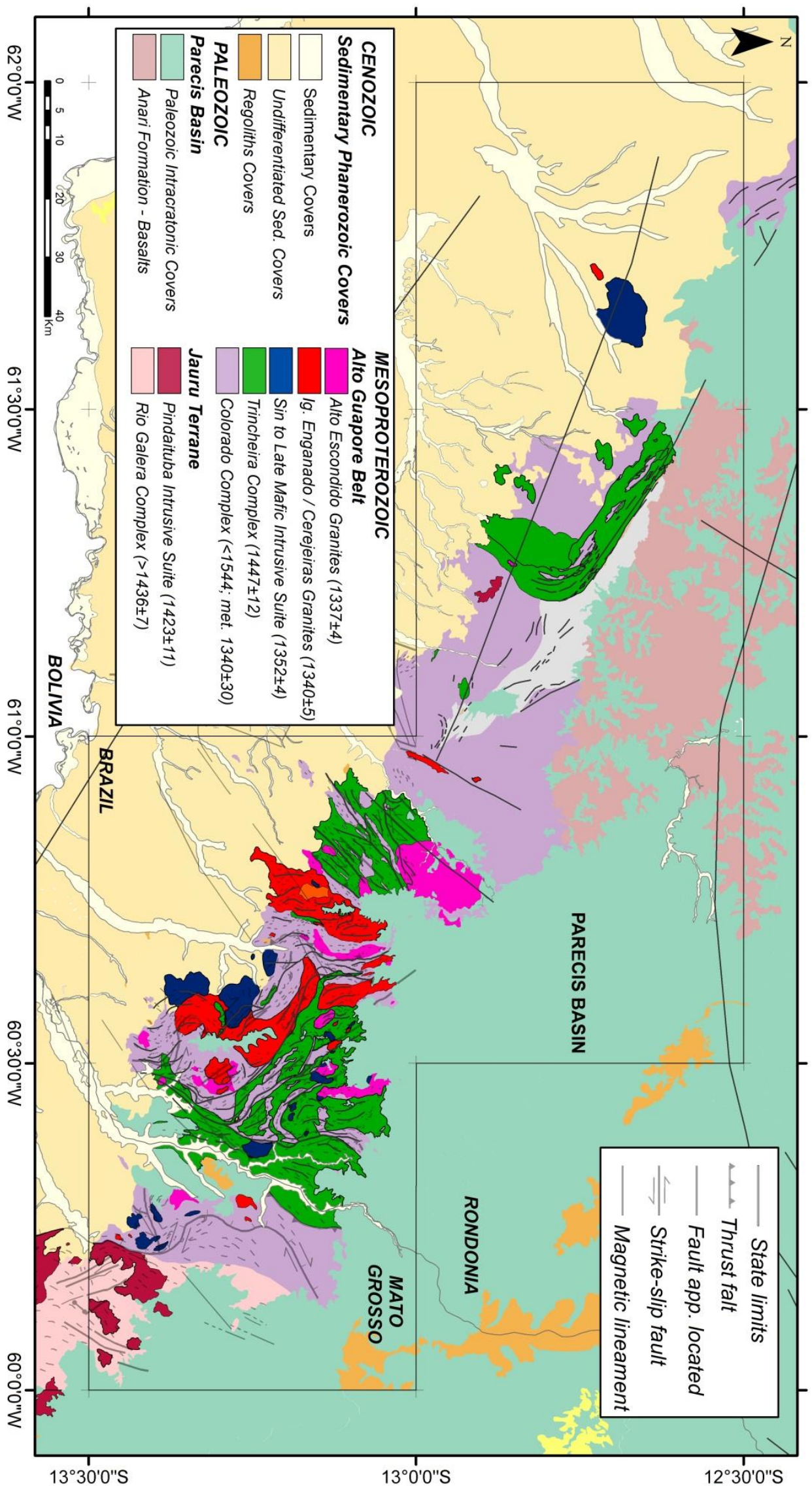

Figure 2 - Simplified geological map of the area of study in the southeast of the state of Rondônia and SW of the Mato Grosso (adapted from Scandolara et al., 1999; Quadros and Rizzotto, 2007; Rizzotto, 2010). 


\subsubsection{Trincheira Mafic-ultramafic Complex}

The Trincheira Mafic-ultramafic Complex is the main unit of the Alto Guaporé Belt and is characterize by an association of mafic-ultramafic rocks containing grabbro, tremolitite, hornblendite and gabbronorite, partly metamorphosed (Pinto Filho et al., 1977; Romanini, 2000)

Due to the geological complexity, Rizzotto and Hartmann (2012) divided it in three sub-units: a) lower unit - cumulate mafic-ultramafic rocks (granulite facies) olivine pyroxene protoliths, bronzitite and websterite; b) intermediate unit - banded amphibolites, with norite, gabbronorite, gabbro, anorthosite, gabbro-anorthosite and rare plagiogranite protoliths (amphibole facies); c) upper unit -fine grained amphibolites, massive and pillowed basalt with alternation of metacherts (BIFs), calc-silicate rocks and schists (amphibolite facies).

The contact with other units is tectonic, and determined by transpressive faults. The mineralogic characteristics and the protholiths of the different types of rocks that conform the Trincheira Complex are shown in Table 1.

Table 1 - Mineralogic characteristics and protholith of the main kind of rocks of the mafic-ultramafic Trincheira Complex (Rizzotto and Hartmann, 2012).

\begin{tabular}{llc}
\hline Lithology & Mineralogy & Protholith \\
\hline Metabasalt & hornblende+plagioclase+epidote+quartz \pm magnetite \pm titanite & Basalt \\
Amphibolite & mg-hornblende+plagioclase+quartz+epidote \pm titanite \pm ilmenite \pm clorite & Gabbro \\
Porphyroblastic & mg-hornblende+plagioclase+quartz+magnetite \pm ilmenite \pm apatite \pm epidote & Gabbronorite \\
amphibolite & plagioclase+clinopyroxene+orthopyroxene+actinolite \pm ilmenite \pm titanite & Gabbro \\
Metagabbro & orthopyiroxene \pm plagioclase \pm cummingtonite & Pyroxenite \\
Meta- & & Norite \\
ultramafic & clinopyroxene+orthopyroxene+plagioclase \pm hornblende \pm ilmenite & Mafic granulite
\end{tabular}

The geochronological records of the Trincheira Complex show an average ${ }^{40} \mathrm{Ar} /{ }^{39} \mathrm{Ar}$ age of $1319 \pm 10 \mathrm{Ma}$, interpreted as regional metamorphic cooling of the Guaporé Belt (Rizzotto et al., 2002). Data obtained from the ratio ${ }^{207} \mathrm{~Pb} /{ }^{206} \mathrm{~Pb}$ on a mafic granulite shows age of $1447 \pm 12 \mathrm{Ma}$, interpreted as the crystallization age of the rock (Rizzotto et al., 2013).

\subsubsection{Colorado Complex}

The Colorado Complex is a metasedimentary sequence occurring in the Guaporé suture and is composed of paragneiss, pelitic schist, calc-silicate gneiss, para-amphibolite and 
banded iron formation. Rocks from this unit, together with those of the Trincheira Complex, make up the regional high-grade metamorphic setting of the Alto Guaporé Belt (Rizzotto and Hartmann, 2012).

The rocks that make up the undifferentiated unit consist of supracrustal of clasticchemical nature, banded and partially migmatized. This unit is formed of plagioclase-biotitequartz gneiss, garnet-sillimanite gneiss, schists with quartz, biotite gneiss, banded iron formation, calc-silicate gneiss, metamarl and talc schists. The metapelitic unit is represented by reddish brown pelitic schits (muscovite-biotite-quartz schist, garnet-silimanite-biotite schist and sillimanite-staurolite-biotite-quartz schist). The metapsamites consist of banded gneiss with migmatitic structures that are alternated within the schists. The Fe-Mn unit is discontinuous and irregular with crests aligned following the regional metamorphic foliation, including lenses of amphibolite and schist with layers of magnetite/hematite 1-2 cm thick (magnetite metachert, hematite quartzite, ferruginous quartzite and manganesiferous metachert). The calc-silicate unit occurs as elongated folded and discontinuous lenses (calcsilicate gneiss consisting of diopside, plagioclase, quartz, actinolite and rare garnet). The paraamphibolite unit occurs as narrow and elongated layers along with calc-silicate gneiss.

Geochronological data obtained from the ${ }^{40} \mathrm{Ar} /{ }^{39} \mathrm{Ar}$ technique on hornblende of two samples of amphibolite showed ages of $1313 \pm 4 \mathrm{Ma}, 1313 \pm 6 \mathrm{Ma}, 1312 \pm 3 \mathrm{Ma}, 1325 \pm 3$ Ma, $1326 \pm 2 \mathrm{Ma}, 1330 \pm 3 \mathrm{Ma}$, with an average of $1319 \pm 10$, and was interpreted as the period of regional metamorphic cooling (Rizzotto et al., 2002).

The paragneiss (metapsamitic unit) yielded ages of upper intercept of $1544 \pm 21 \mathrm{Ma}$ (U-Pb method), derivated from an igneous source, considered by the authors to be related to the main source of sediments and maximum age of sedimentation. The age $1340 \pm 30 \mathrm{Ma}$, determined on metamorphic zircon, was interpreted as the metamorphic peak recorded in the Colorado Complex (Rizzotto, 2010).

\subsubsection{Syn to late mafic intrusive suite}

There are three main groups of rocks: ultramafics of the Morro Sem Boné and Morro do Leme, mafic-ultramafic Igarapé Hermes and mafics Cidade do Colorado (Rizzotto, 2010). The Serra Céu Azul Intrusive Suite was not included in this association; however, the unit contains rocks with a high-potential for mineralizations of $\mathrm{Cr}, \mathrm{Ni}$ and $\mathrm{Cu}$ (Romanini, 2000).

The ultramafic of Morro Sem Boné consists of serpentinites on the upper portion, with intercalated silcretes and lateritic siliceous layers. Morro do Leme comprises layered bodies of serpentinized dunites and peridotites and, in lesser proportion, hornblendites and 
tremolitites (Rizzotto, 2010). The mafic rocks of Cidade do Colorado unit are, in a general way, represented by layered gabbros and metagabbros, with incipient regional deformation. The mafic-ultramafic Igarapé Hermes rocks consist of coarse-grained metagabbros and hornblendites, and occur in the form of large boulders, in the southeastern part of the study area.

The crystallization age of leucogabbro in the Cidade do Colorado Mafic unit yielded an age of $1352 \pm 4 \mathrm{Ma}(\mathrm{U}-\mathrm{Pb}$ method) (Rizzotto et al., 2002).

\subsubsection{Syn-to late tectonic intrusive granites}

The rocks of the Igarapé Enganado Intrusive Suite comprise medium to coarse-grained syenogranite, monzogranite, granodiorite and rare tonalite with metaluminous to peraluminous chemical signature. They have light color, and a foliation of magmatic flow as main feature. The Cerejeiras Intrusive Suite comprises gray and pinkish, coarse-grained, inequigranular to porphyritic granites with a characteristic foliation of magmatic flow. Lithochemistry and petrogenesis of this suite are similar to those of the Igarapé Enganado Suite. Rizzotto (2010) analyzed samples of granodiorite, using the U-Pb (SHRIMP) method, and presented a result of $1340 \pm 5 \mathrm{Ma}$, interpreted as the igneous crystallization age. In the same sample, Sm-Nd isotopes analyses supplied TDM model ages of 1.58 to $1.51 \mathrm{Ga}$.

\subsubsection{Syn- to post-tectonic intrusive granites}

The granites of the Alto Escondido Suite are homogeneous, leucocratic with gray to pink color an incipient fabric of magmatic flow, fine-grained (biotite monzogranite and garnet-biotite syenogranite). Dating on a sample of biotite syenogranite was performed, using the U-Pb (SHRIMP) method, which gave an age of 1340 $3 \mathrm{Ma}$, interpreted as the age of crystallization (Rizzotto, 2010). The results of the Sm-Nd method of this sample indicated ages TDM model of $1.51 \mathrm{Ga}$ and $\varepsilon \mathrm{Nd}(\mathrm{T})+2,35 \mathrm{Ga}$, which suggests juvenile magma. The second analysis (equigranular syenogranite) supplied an age of $1337 \pm 4 \mathrm{Ma}$, using the $\mathrm{U}-\mathrm{Pb}$ (SHRIMP) method.

\subsubsection{Paleozoic intracratonic covers}

The Paleozoic covers include the Corumbiara Formation and the units that make up the Parecis Group. Bahia and Pedreira (1998) and Bahia (2007) studied, respectively, the glaciogenic deposits of the Pimenta Bueno Formation and the tectono sedimentary evolution 
of the Parecis Basin. The Corumbiara formation comprises a sedimentary package of conglomerates and immature sandstones, diamictites and carbonates. The Parecis Group, in this area, is represented by several formations, such as Anari (basalt, diabase and microgabbro), Rio Avila (bimodal sandstones) and Utiariti (quartz-sandstone).

\subsubsection{Undifferentiated sedimentary covers}

The Holocenic covers recorded in this region consist of the Guaporé Formation and undifferentiated sedimentary covers and represent a large area, apart from the lateritic cover, distributed all over the work area.

\section{Materials and methods}

\subsection{Airborne geophysical data}

The airborne geophysical survey in the southeastern of Rondônia was carried out by the partnership of LASA Engenharia e Prospecções S.A. and Prospectors Aerolevantamentos e Sistemas LTDA., for CPRM/SGB - Geological Survey of Brazil. The airborne geophysical survey was performed during the period 2005-2006, in the southeastern part of Rondônia state and part of the northwestern limit of Mato Grosso state, covering 93,189.12 km of aeromagnetic and aero-gamma-spectrometric profiles with high resolution data. The aeromagnetic system used in the aerial survey consisted of a cesium steam sensor located on the rear of the aircraft (stinger type), with a resolution of $0.001 \mathrm{nT}$. The magnetometric readings were performed every 0.1 second, which is equivalent at a speed of $280 \mathrm{~km} / \mathrm{h}$ of the aircraft to approximately $7.8 \mathrm{~m}$ on the terrane. The gamma spectrometric system used, Exploranium, model GR-820, measured the natural gamma radiations spectrum, discriminating 256 spectral channels with a detecting system consisting of two sets of crystals (thallium-activated sodium iodide) downward looking with 1024 cubic inches each (total volume of 2048 cubic inches) and two crystals upward looking, with 256 cubic inches each (totalizing 512 cubic inches; CPRM/LASA Engenharia e Prospecções S/A, 2006). The gamma spectrometric readings were performed each second, representing measures at intervals of approximately $78 \mathrm{~m}$ on the surface.

The spacing between N-S flight lines and E-W control lines is $0.5 \mathrm{~km}$ and $10 \mathrm{~km}$, respectively. The nominal height of flight was fixed at $100 \mathrm{~m}$ above the surface. The Sudeste de Rondônia aerial survey has an irregular shape because it includes a border region, where a distance of 10 kilometers from the Brazil-Bolivia borderline must be preserved (Fig. 3). 


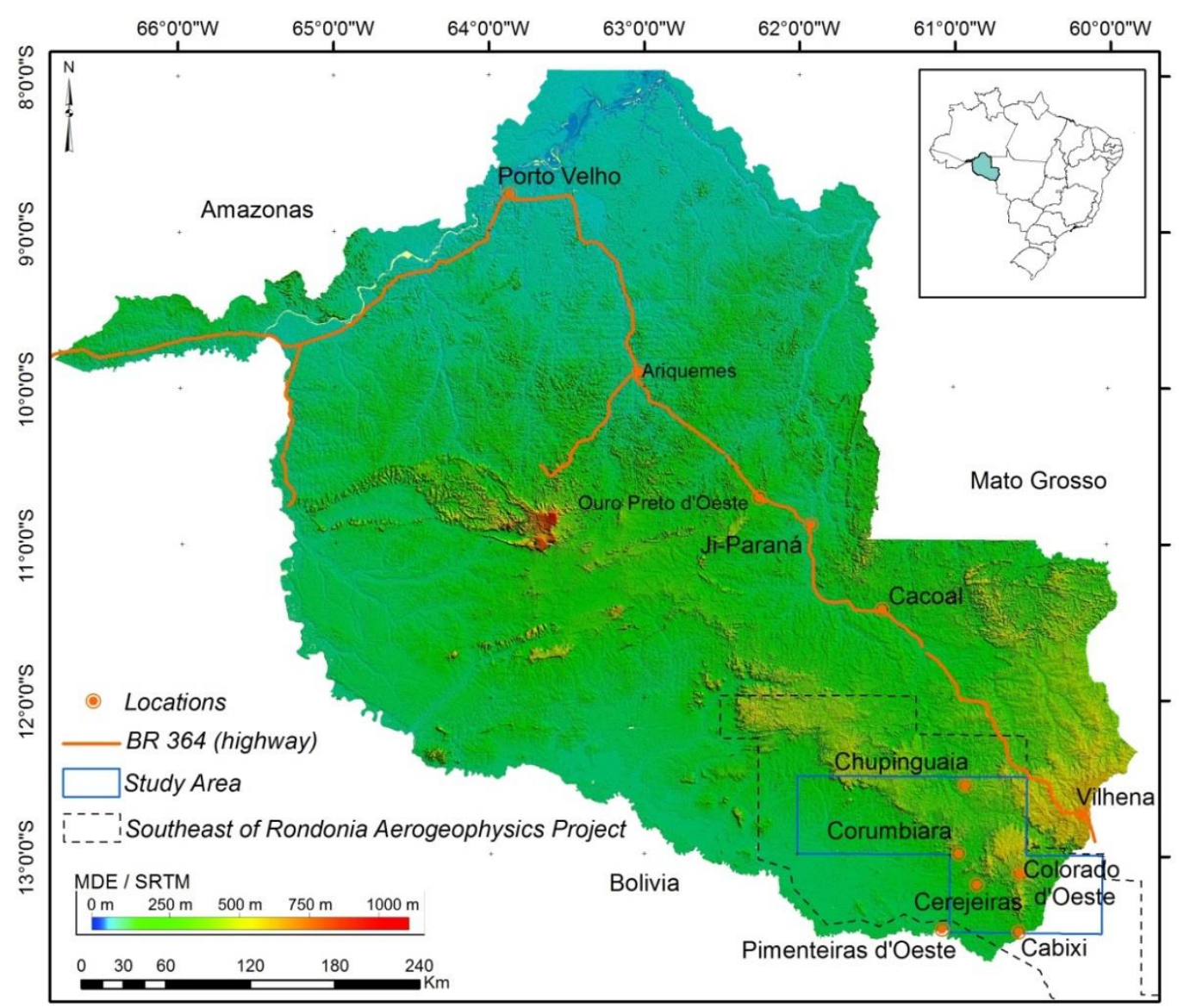

Figure 3- Digital elevation model of the state of Rondônia generated from SRTM (Shuttle Radar Topographic Mission) data, indicating the position of the Sudeste de Rondônia Aerial Survey (CPRM, 2006), study area, main access roads and counties. Note that the area of the survey is located, in a geographical context, in the southeast of Rondônia and northwest portion of the state of Mato Grosso. In the region close to the Brazil/Bolivia border there is a gap of 10 kilometers from the borderline.

\subsection{Geological Data}

The geological and mineral resources maps of Rondônia state (Scandolara et al., 1999, Quadros and Rizzotto, 2007), and the maps of the Guaporé Project Folha Pimenteiras (SD.20X-D) and Vilhena (SD.20-X-B) (Rizzotto, 2010 and Rizzotto, 2014) were used as support for the development of this work. The geological-geophysical integration map (Oliveira et al., 2015), based on the interpretation of aeromagnetic and gamma spectrometric data was also considered.

\subsection{Geochronological Data}

In order to understand the crustal evolution of the Alto Guaporé Belt, isotopic geochemical data, Sm-Nd, U-Pb and Ar-Ar of several researchers (Ruiz, 2005; Scandolara, 2006; Rizzotto, 2010; Rizzotto et al., 2013) were integrated and used as reference for geochronological interpretations. 


\section{Geophysical Data Processing}

The data from the Sudeste de Rondônia aerial survey was pre-processed by LASA Engenharia e Prospecções S.A. and Prospectors Aerolevantamentos e Sistemas LTDA. All the procedures of reduction of data performed by them were considered as definitive, thus all the processing done was based on the final geophysical information provided: the magnetic information, expressed by the total magnetic intensity (TMI), i.e. the total field measured, with the daytime geomagnetic variation correction and the geomagnetic field correction (IGRF); the gamma spectrometric information, given in separate energetic bands referring to the total energy band (channel of total count) expressed in $\mathrm{mR} / \mathrm{h}$, to the potassium channels, expressed in percentage, to the uranium and thorium channels in terms of micro-equivalent, pertinently corrected in dead time; energy variations (spectrum stabilization) of the respective levels of bottom radiation; height variations related to the nominal height established for the project; and layout due to the Compton effect. The processing included the leveling and micro-leveling of profiles for both sets of data (CPRM/LASA Engenharia e Prospecções S/A, 2006).

The pre-processing was carried out using the Oasis Montaj TM software (version 8.2.0.5), in which the original data, obtained from lines (flight lines with N-S direction), was transformed into regular grid format using the bi-directional interpolator, appropriate for data arranged in parallel lines, since it accentuates the tendencies that appear perpendicular to the flight lines. The cell size $125 \mathrm{~m}$ x $125 \mathrm{~m}$ was used to interpolate, and it represents $1 / 4$ of the flight line spacing. Gunn et al. (1997b) state that an interpolation routine for magnetic data will only produce realistic interpolation if the unit cells do not exceed $20-25 \%$ of the line spacing.

\subsection{Magnetometry}

The magnetometric information represents the influence of at least three sources: (i) internal, due to the geomagnetic field, created in the mantle-core interface; (ii) external, coming from the influence of several electrical currents established in the ionosphere and (iii) from the crustal magnetic sources (represented by the differences in local concentrations of magnetic geologic material), located above the Curie surface for magnetite, which is the main magnetic source of geologic material. The elimination of the influence related to the main magnetic field is performed using an appropriate mathematic model, the IGRF/DGRF (International/Definitive Geomagnetic Reference Field). The removal of the contribution related to external sources is performed through the correction of the daytime geomagnetic 
variation (Solar Quiet). The final product of these two corrections is the total magnetic intensity (TMI), which represents the variations of magnetite concentration in crustal geologic material and features imposed on them.

The products calculated from the TMI were: the horizontal derivatives (Dx and Dy), the vertical derivative $\left(1^{\text {st }} \mathrm{Dv}\right)$, the total horizontal derivative (THD; Blakely,1996), the analytic signal (AS; Nabighian, 1972), the tilt derivative (TD; Miller and Singh, 1994; Salem et al,. 2009) and the pseudo-gravity (Baranov, 1957) (Fig. 4). Besides these products, upward continuation maps $500 \mathrm{~m}$ and $10,000 \mathrm{~m}$ were created. The qualitative interpretation of these products allowed the generation of the lineaments and magnetic domains.

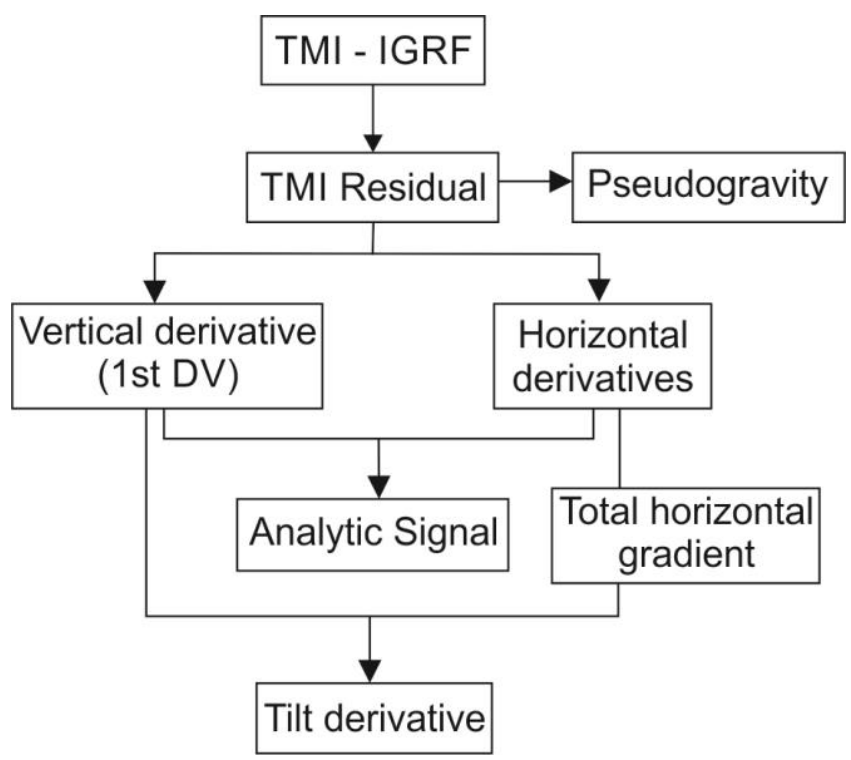

Figure 4 - Flowchart showing the sequence of aeromagnetometric data processing.TMI - total magnetic intensity; Horizontal derivates - first horizontal derivate in $\mathrm{x}$ and $\mathrm{y}$ of the anomalous magnetic field; $1 \mathrm{st} \mathrm{dv}$ - first vertical derivate of the anomalous magnetic field; ASA - analytical signal amplitude.

The power spectrum of the aeromagnetometric data was calculated and analyzed using the Spector and Grant model (1970). An estimate of the depth of the top of the magnetic anomalies was determined, using the relationship between the wavelength $(\lambda)$ and the wave number $(\mathrm{K}), \lambda=(2 \pi / \mathrm{K}) \delta$, where $\delta$ is the flight line spacing. The spectral values of the signal show that there are three groups of magnetic anomalies located at different depths. It was possible to estimate the top of the anomalies with wavelengths greater than $4.3 \mathrm{~km}$, which are located between 3 and $15 \mathrm{~km}$ deep. The anomalies with wavelengths between $4.3 \mathrm{~km}$ and 720 $\mathrm{m}$ are located between 3 and $1 \mathrm{~km}$ deep, and the anomalies with the top at depths lower than 1 $\mathrm{km}$ present wavelengths lower than $720 \mathrm{~m}$. The analysis of the power spectrum indicates that 
the magnetic anomalies of the study area are generated mostly by shallow sources, $<1 \mathrm{~km}$ deep, with contribution of deep magnetic sources that can reach more than $15 \mathrm{~km}$ in depth.

The TMI represents the magnetic field produced by the magnetic sources present in the area of study, without the influence of the earth's magnetic field. The magnetic anomaly of a finite body invariably includes positive and negative elements created by the dipolar nature of the Earth's magnetic field (Fig. 5-A). A common processing operation is the reduction to the pole, which involves the conversion of the anomalies to their equivalent on the magnetic north pole (Baranov and Naudy, 1964). This process, in general, simplifies the magnetic anomalies, transforming dipolar anomalies into monopolar ones. The studied area is located on a low magnetic latitude (below $15^{\circ}$ ), which complicates the performance of a satisfactory reduction to the pole processing of the TMI with available algorithms (Cordani and Shukowsky, 2009; Rajagopalan, 2003; Wijins et al., 2005; Fairhead and Williams, 2006; Getech, 2007; Geosoft Inc., 2011).

The horizontal derivatives (Dx and Dy) (Fedi and Florio, 2001; Verduzco et al. 2004; Cooper and Cowan, 2006) show the horizontal variations of the anomalous magnetic field and highlight major changes of the field on the directions $\mathrm{x}$ (Dx) and $\mathrm{y}$ (Dy) (Phillips, 2000). Computation of the first vertical derivative (Dz) in an aeromagnetic survey is equivalent to observing the vertical gradient directly with a magnetic gradiometer and has the same advantages (Fig. 5-B), namely enhancing shallow sources, suppressing deeper ones, and giving a better resolution of closely-spaced sources (Reeves, 2005).

The total horizontal derivative (THD) is calculated from the horizontal derivates (Nabighian, 1984) and defines abrupt lateral changes, indicating lithologic and structural changes. As in Dx and Dy, this product enhances high gradients, showing the shallower information (Phillips, 2000), and it is given by the following formula:

$$
\begin{aligned}
& \left|\vec{A}_{n}(x, y)\right|=\sqrt{\left[\frac{\partial}{\partial x}\left(\frac{\partial^{n} M}{\partial z^{n}}\right)\right]^{2}+\left[\frac{\partial}{\partial y}\left(\frac{\partial^{n} M}{\partial z^{n}}\right)\right]^{2}} \\
& n=0,1,2, \ldots
\end{aligned}
$$

The analytic signal represents a technique used in the analysis of signals in electronics, where a larger amount of information is obtained from a real function through its transformation into a complex function. The quadrature information (imaginary part of the signal) is obtained through the Hilbert transformation of the real part. This way, the analytic signal of order $\mathrm{n}$ of the anomalous magnetic field (M) can be represented as follows (Roest et al. 1992): 


$$
\begin{aligned}
& \vec{A}_{n}(x, y)=\frac{\partial}{\partial x}\left(\frac{\partial^{n} M}{\partial z^{n}}\right) \hat{x}+\frac{\partial}{\partial y}\left(\frac{\partial^{n} M}{\partial z^{n}}\right) \hat{y}+i \frac{\partial}{\partial z}\left(\frac{\partial^{n} M}{\partial z^{n}}\right) \hat{z} \\
& n=0,1,2, \ldots
\end{aligned}
$$

This concept was presented by Nabighian (1972) when studying the potential fields, the magnetic case, aiming to find a semi-automated process of interpretation of the generating sources of a magnetic field. It is based on the horizontal derivates (real part) and vertical derivate (imaginary part) of the magnetic field. This transformation turns the position indications independent from the magnetic latitude where they are located, and from the presence of remaining magnetization in the sources involved (Roest et al., 1992), since this indication is more dependent on the horizontal magnetic gradient (Blakely, 1996).

This is an efficient technique for determining geometric parameters, such as in the tracing of area limits of the sources (either geologic or structural) and it can even supply an estimate of the depths of these sources. This technique has been improved since its conception by Nabighian (1974) and by others (Rao et al., 1981; Thompson, 1982; Murthy, 1985; Blakely and Simpson, 1986; Blakely, 1996).

The analytic signal (Fig. 5-C) is a symmetric function, whose peaks are centered on the edges of the anomalous body or on the geologic feature that corresponds, allowing its mapping (Nabighian 1972, 1984; Roest et al. 1992; Hsu et al. 1996). It is given by:

$$
\begin{aligned}
& \left|\vec{A}_{n}(x, y)\right|=\sqrt{\left[\frac{\partial}{\partial x}\left(\frac{\partial^{n} M}{\partial z^{n}}\right)\right]^{2}+\left[\frac{\partial}{\partial y}\left(\frac{\partial^{n} M}{\partial z^{n}}\right)\right]^{2}+\left[\frac{\partial}{\partial z}\left(\frac{\partial^{n} M}{\partial z^{n}}\right)\right]^{2}} \\
& n=0,1,2, \ldots
\end{aligned}
$$

The analytic signal shows more advantages if compared to the reduction to the pole, when applied with the same goal, the localization of the magnetic sources, mainly on low magnetic latitudes, where the transformation operator of phase is unstable (MacLeod et al. 1993; Blakely, 1996, among others). Furthermore, in order to have geological meaning, the transformation reduction to the pole should incorporate the remanent magnetization, which is always present in geologic material. As it is known, the real spatial mapping of this physical property is a difficult task, almost impossible to perform, which normally makes the phase transformation to be incomplete. The indication of source positioning from the analytic signal amplitude is independent from the previous knowledge of the remanent magnetization and is more effective as the geometry of the source approaches a dikes. 

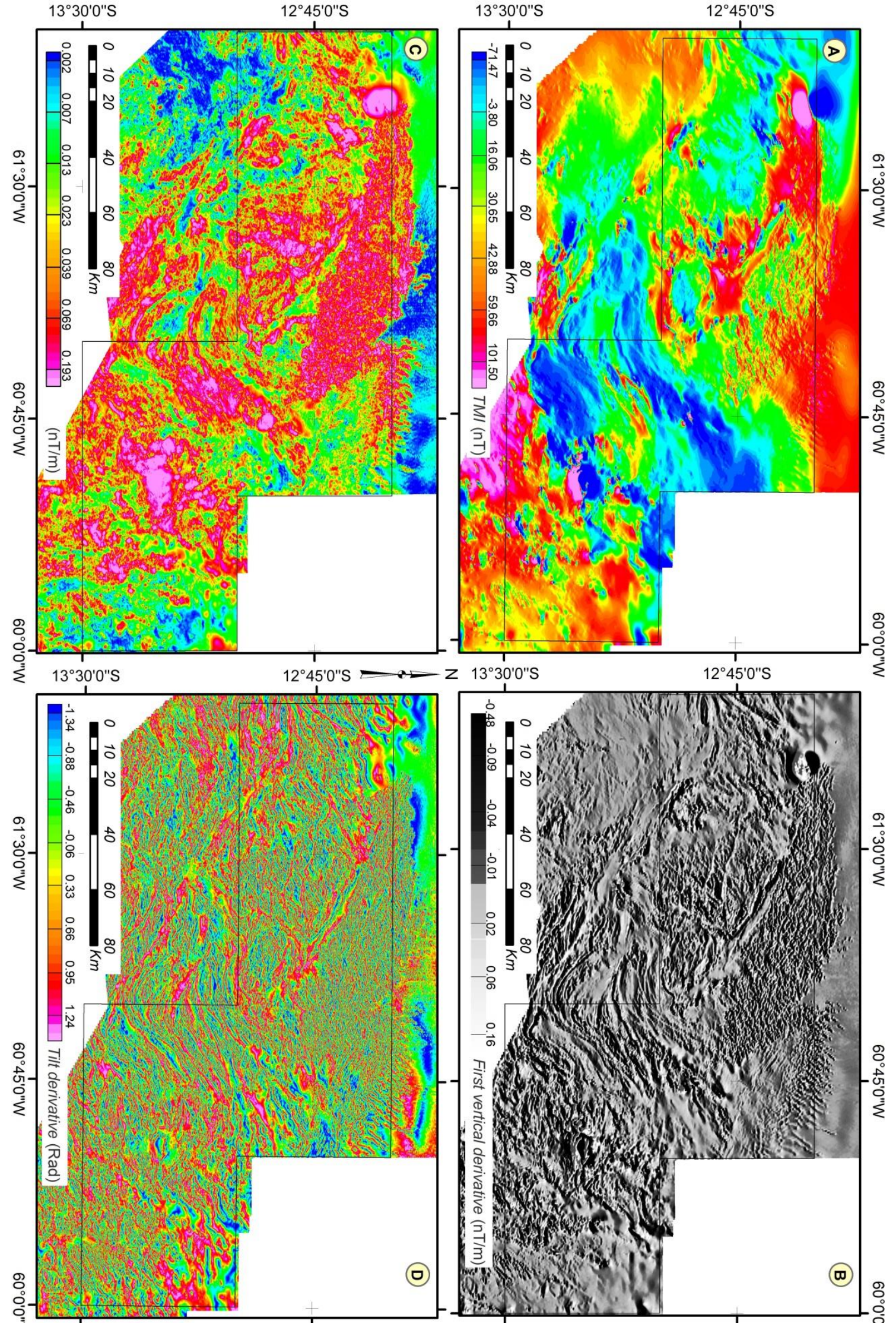

Figure 5 - (A) Total magnetic intensity - TMI - with shaded magnetic relief and also illumination inclination and declination at $45^{\circ}$; (B) First vertical derivative $-1^{\text {st }}$ Dv of the TMI; (C) analytic signal amplitude of the TMI; (D) analytic signal tilt from the total magnetic intensity. 
The tilt derivative (Fig. 5-D) defines the spatial behavior of the analytic signal vector on the vertical plane that contains the resulting horizontal component on the considered point. It has shown to be efficient when mapping linear features of the magnetic relief (commonly relatable to the textural/structural features of the underlying geologic material) and, due to its spatial arrangement and relative texture, when delimiting the different magnetic units, features sometimes little apparent on the analytic signal amplitude.

The pseudo-gravity is one of the several techniques from the Fourier transformation that can be applied in aeromagnetic data (Pratt and Shi, 2004). Pseudo-gravity enhances anomalies associated to deep magnetic sources in relation to shallow magnetic sources (Fig. 6-A). This transformation is an excellent interpretation tool to detect depths as well as magnetic sources and igneous plutons. The data can be modeled using conventional gravimetric modeling tools. The pseudo-gravity map of the southwest of Rondônia exhibits a separation of large tectonic domains that indicate environments of different depths.

For comparison purposes, a gravimetric map of Bouguer anomaly was created from the TOPEX/Poseidon satellite data (Fig. 6-B). The models created show considerable correlation with the pseudo-gravity map, where the main similarity is the differentiation of the limit between the Alto Guaporé Belt and the Jauru Terrane, defined by a gravimetric low. Several authors admit using satellite data for studies related to the mapping of tectonic features, crustal thickness, as well as the localization of targets for geodynamic modeling (Mariani et al., 2003; Mishra et al., 2003; Mikhailov et al., 2004; Meijde and Assumpção, 2013). 


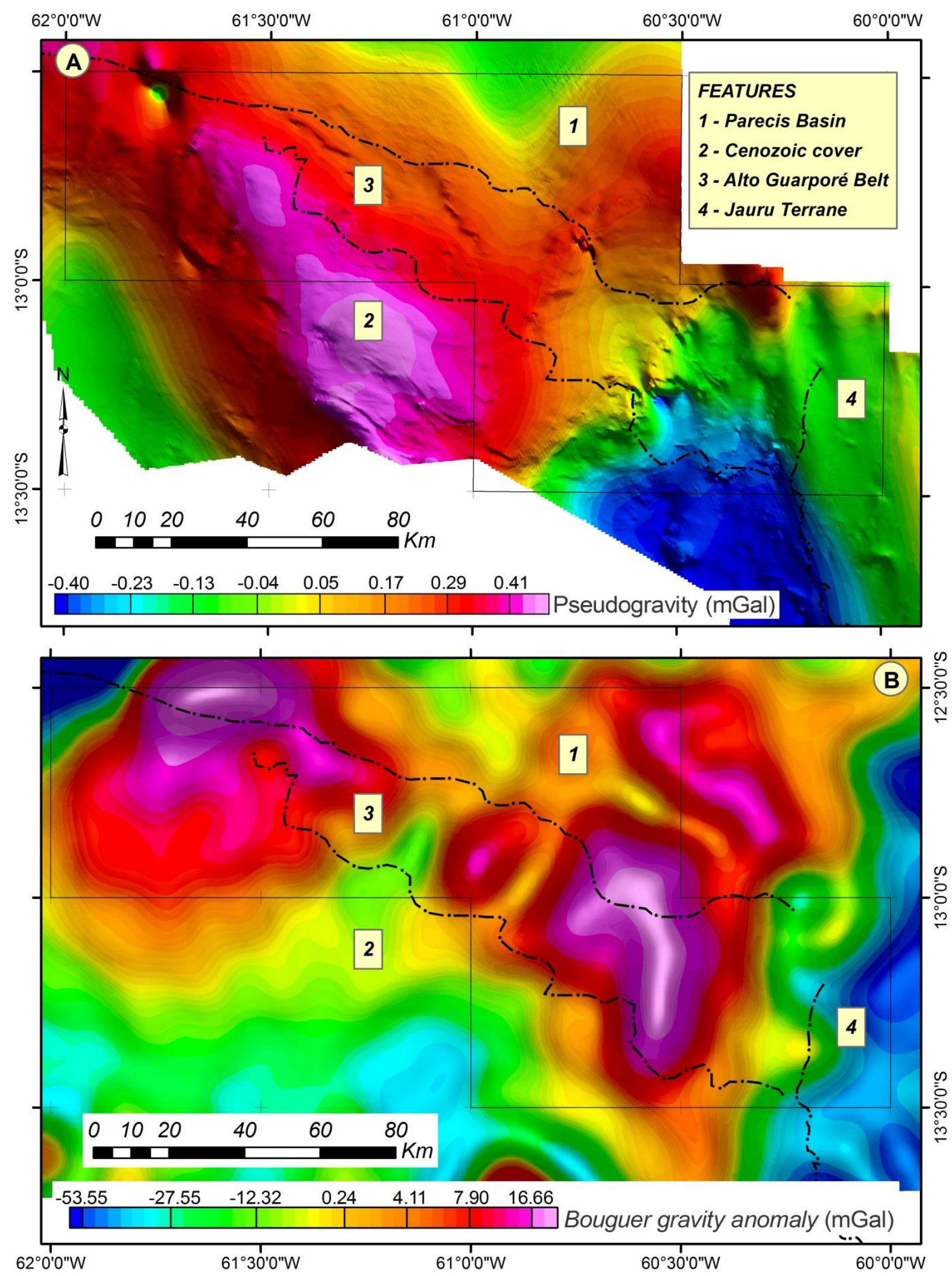

Figure 6 - (A) Pseudo-gravity map resulting from the Fast Fourier Transformation processing from the Anomalous Magnetic Field. (B) Bouguer Anomaly Map created from TOPEX satellite data. Density contrast $2.68 \mathrm{~g} / \mathrm{cm}$. 


\subsection{Gamma ray}

The concentration values obtained in the gamma spectrometry are derived from a direct relationship of the intensity of the captured radiation, and then transformed into concentration equivalents through mathematical models. The maps showing the gamma spectrometric data were created from interpolation, using the minimum curvature method (Briggs, 1974), due to the favoring of the radiometric anomalies along the flight lines direction (IAEA, 2003). The three radioelement channels (Potassium in \%, equivalent thorium in ppm and equivalent uranium in ppm) are the base of the subsequent processing (Fig. 7) and the final products for analysis are ternary images in false-color RGB (KThU) and CMY (KThU), containing the total radiation count (Fig. 8), anomalous uranium and anomalous potassium (Saunders et al. 1994; Pires, 1995).

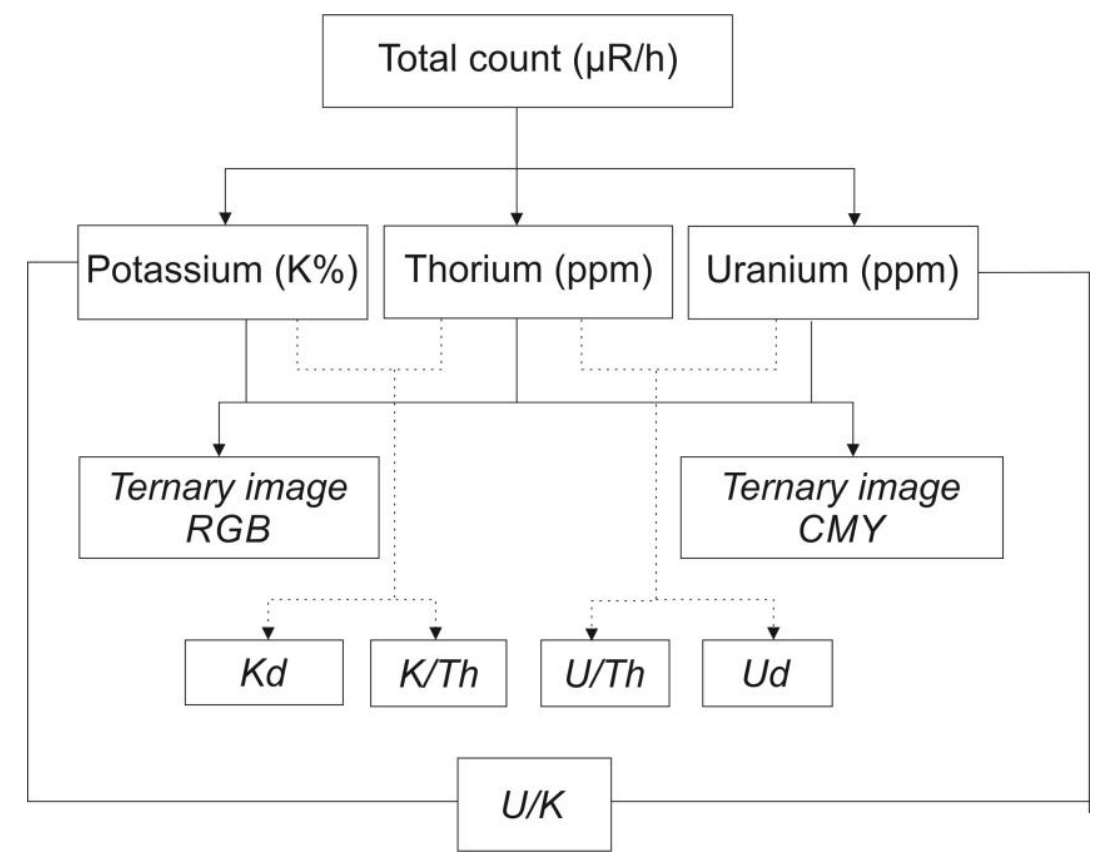

Figure 7 - Gamma spectrometric data processing flowchart. RGB (KThU) - ternary false-color image where the concentration of each radioelement is expressed in proportion to an intensity of primary color. CMY (KThU) ternary false-color image where the concentration of each radioelement is expressed in proportion to an intensity of Cyan, Magenta and Yellow. Kd - Anomalous potassium. Ud - Anomalous Uranium.

The potassium, thorium and uranium concentration maps indicate a lateral variation of concentration of these elements obtained through a processing that takes into account the intensity of the radiation received in a frequency interval characteristic of each radioelement. The received radiation depends on variables such as the concentration of the radioelement in the source, the distance of the detector (flight height) and the humidity level of the source (IEAE, 2003). The concentration of these elements in the crust vary according to the nature of the rocks. 
Ternary maps of RGB (KThU) (Fig. 8-D) and CMY (KThU) pseudo-color showed to be an efficient way to represent the lateral variation of the three elements. In these products, the concentration of each radioelement is represented by the variation of color intensity. When combined, they create secondary colors indicating high concentration of two or more radioelements. Within the context of this work, the $\mathrm{K}$, Th and $\mathrm{U}$ values are represented with red, green and blue respectively in the RGB map; and cyan, magenta and yellow respectively in the CMY map. 

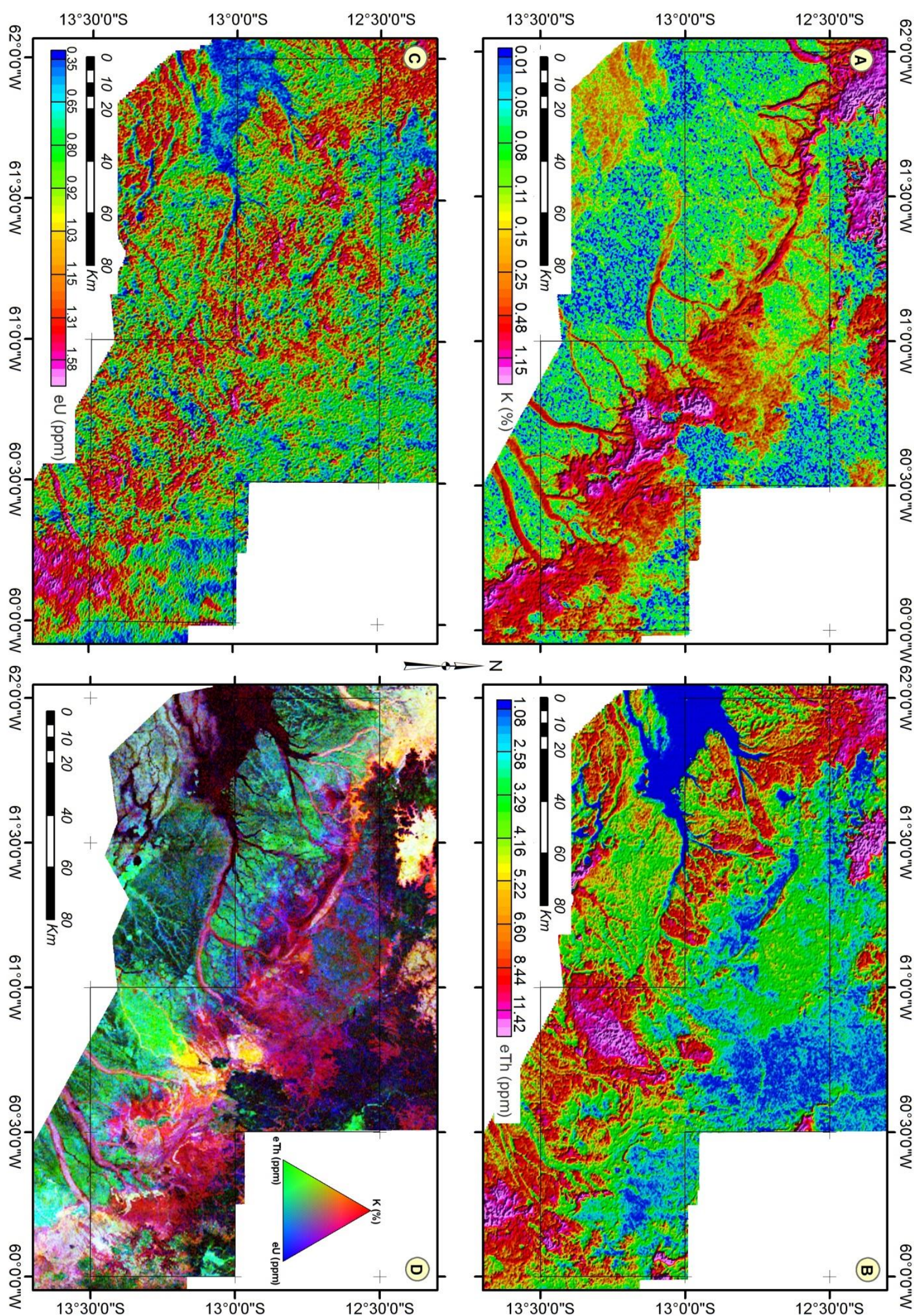

Figure 8 - Airborne gamma spectrometric maps, where: (A) radiometric map of potassium distribution - K; (B) radiometric map of thorium distribution - eTh; (C) radiometric map of uranium distribution - eU; (D) radiometric map of the ternary composition - RGB (KeTheU). 


\section{Structural Framework}

The analysis of the anomalous magnetic field relief was aided by its linear transformations, mainly those referring to the analytic signal amplitude, delimiting the position of magnetic sources, tilt derivative, whose textural pattern is extremely important in the characterization of the magnetic domains and linear features. The derivatives assisted understanding the relative spatial position of these sources, particularly the horizontals derivatives aided delimiting them on maps.

Images of the horizontal and vertical derivatives were used, as well as the tilt derivative in order to define linear features that could be interpreted as signatures related to deformations that affected the area. That means a product with magnetic lineaments that synthesizes the linear features at different depths was created to represent the structural framework. Based on these observations, three structural domains were defined (D1, D2, D3) in the Alto Guaporé Belt (Fig. 9), described as follows.

The lineaments related to the D1 domain are predominant in the study area. However, considerable part of these magnetic lineaments is covered by Cenozoic sediments of the Guaporé Basin, making it difficult to understand the structuration of this event using field structural data. The D1 structuration presents a sinuous geometry with a preferential direction N50W. In the center part of the area these lineaments flex to NE, in an "S" shape, returning to N50W in the east. This zone is delimited on the analytic signal map by an increase in the magnetic amplitude and in the density of magnetic lineaments. The morphology of these lineaments suggests sinistral movement, where the crustal segment located in the east shifted to NE in relation to the crustal segment in the west of the area. In the east, the interpretation exhibits a zone approximately $32 \mathrm{~km}$ wide by $36 \mathrm{~km}$ long with high magnetic amplitude and large density of magnetic lineaments in N50W direction. This zone is limited in the east by a strong magnetic gradient characterized by anastomosed structures in a NNW trend, which truncate the lineaments of the domain D1, delimiting the D2 pattern.

According to Rizzotto (2010) and Rizzotto et al. (2013), the structuration of the Alto Guaporé Belt is characterized by large ductile shear zones and syntectonic crenulation that align previous structures. By analogy, the D1 domain is probably related to these structures, and occurred between 1.459 and $1.329 \mathrm{Ma}$, according to geochronological data (Rizzotto et al., 2013). The D2 domain is associated to the anastomosed lineaments with a NNW trend verified in the southeastern region of the area. These lineaments truncate the D1 linear structures, and characterize the strong magnetic gradient that delimits the magnetic crustal segment in the west and a weak magnetic crustal segment in the east. This discontinuity 
follows the same structural trend of the Rio Vermelho lineament (Pindaituba Intrusive Suite) in the Jauru Terrane, probably associated to the Sunsás orogeny.

The D3 domain is characterized by large straight magnetic lineaments with N35E, EW, N50W and N20W directions which cut through the whole research area. These lineaments are possibly related to brittle structures that reproduce the crustal anisotropy generated during the D1 and D2 events. The greater density of these magnetic lineaments is observed on the north side of the area, which corresponds to the southern border of the Colorado Graben, Parecis Basin. These structures were possibly activated during the Parecis Basin opening in the Paleozoic.

The analytic signal (AS) of the upward continuation of $10 \mathrm{~km}$ and the pseudo-gravity map allowed the identification of features and magnetic lineaments related to the deep structuration of the crust in the region of Alto Guaporé. There are lineaments observed in two preferential directions: N35E and N50W. The discontinuities defined by these lineaments coincide with the truncation and interference of shallow lineament structure zones, indicating that the discontinuities can be related to the agglutination of terranes, evidenced by the different magnetic signatures, defining the limits between the Alto Guapore Belt and the Paraguá and Jauru Terranes, previously defined by Rizzotto et al. 2013 (Fig. 10). 


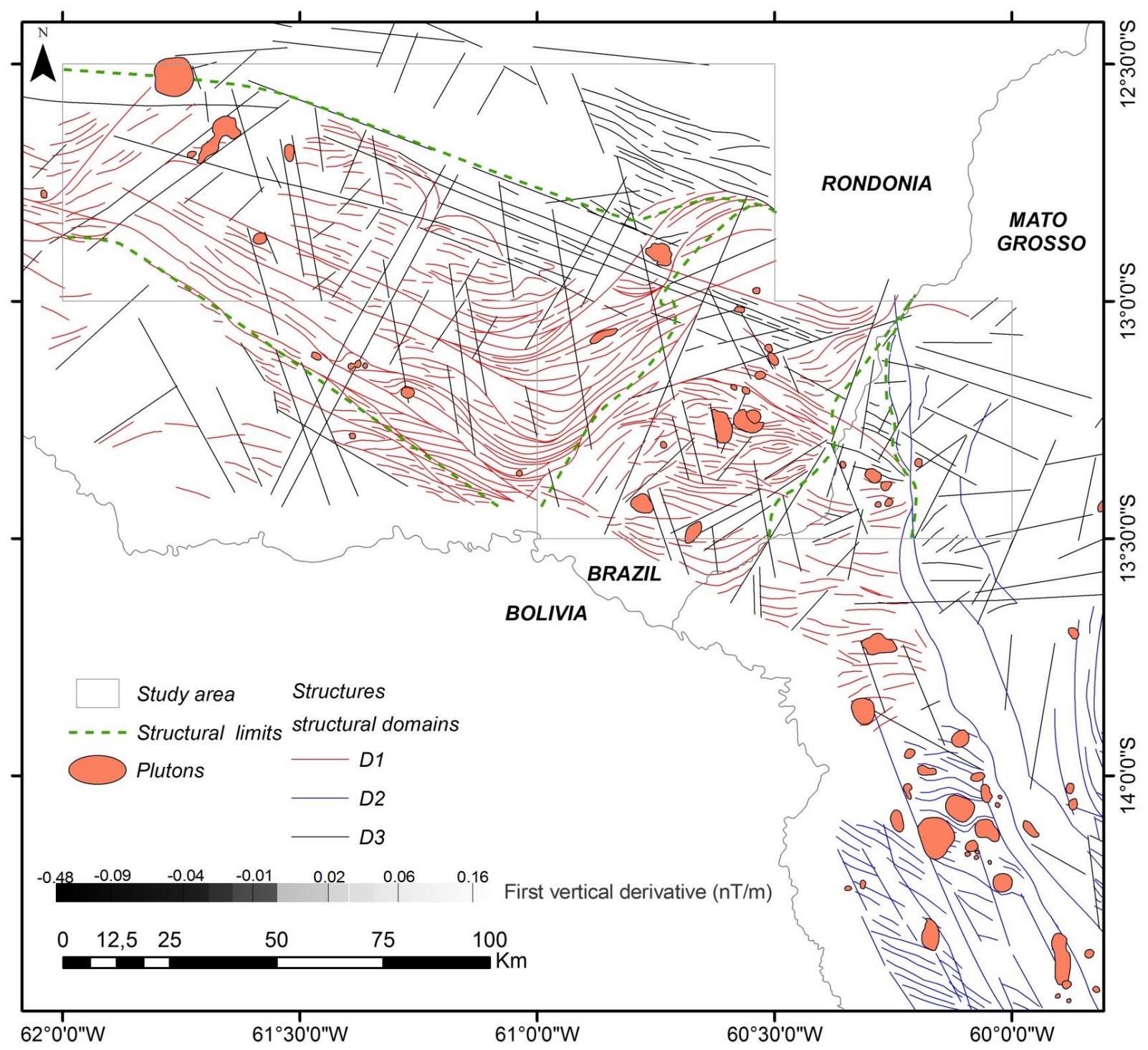

Figure 9 - Magnetic lineaments map interpreted from the horizontal and vertical derivatives and from the tilt derivative, putting on evidence the distinction of the magnetic structures. The magnetic sources with high magnetic amplitude and small wavelength were individualized to aid in the identification of plutons still not mapped. 


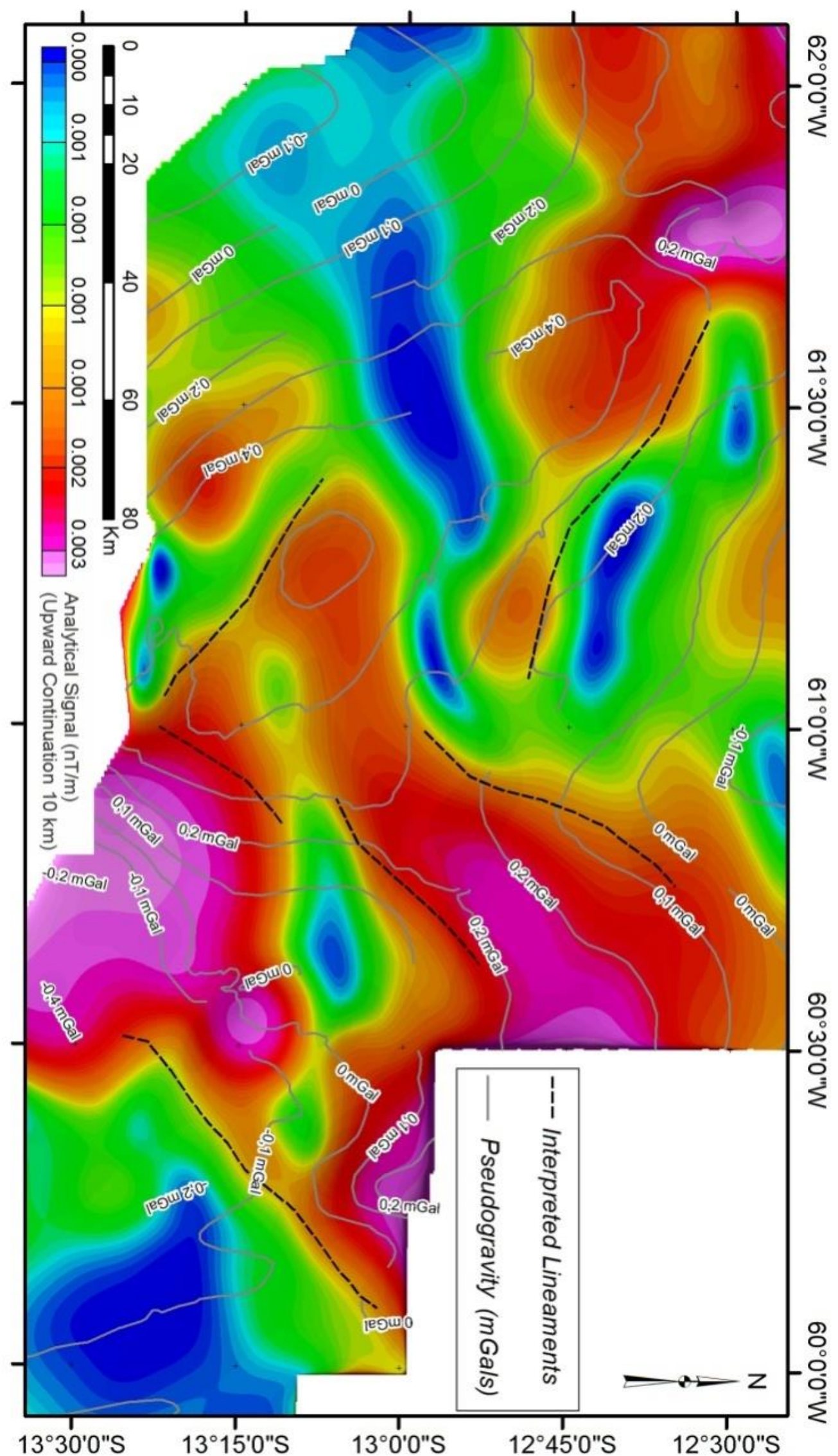

Figure 10 - Analytic Signal map from the upward continuation $10 \mathrm{~km}$ from the surface as reference. The contour lines were extracted from the pseudo-gravity map. 


\section{Lithologic-Geophysics Association}

\subsection{Magnetic Domains}

The identification of magnetic domains is essential for the qualitative interpretation of the data, and involves the delimitation of areas with different magnetic anomaly patterns that must represent different geologic units (Reeves, 2005). Due to the geologic complexity and the size of the area, a reclassification of the AS was defined in five uniform classes, based on the resampling of values in $\mathrm{nT} / \mathrm{m}$, shown on Table 2 . The qualitative interpretation shows five classes of magnetic domains (Fig. 11). The magnetic domains were discriminated according to the texture and intensity of the magnetic response.

Table 2 - Analytic Signal Amplitude Classes. The reclassification allowed the differentiation of large magnetic domains, mafic/ultramafic bodies, I-type granites.

\begin{tabular}{|c|c|c|c|}
\hline Analytical Signal & Range (nT/m) & Rocks & Symbol \\
\hline $\operatorname{High}(H)$ & $>0,224$ & $\begin{array}{l}\text { Trincheira Complex, mafic plutons, } \\
\text { banded iron formation and I-type } \\
\text { granites }\end{array}$ & \\
\hline Medium to high $(M H)$ & $0,082-0,224$ & $\begin{array}{l}\text { Trincheira mafic-ultramafic } \\
\text { complex, mafic granulites and } \\
\text { Anari basalt }\end{array}$ & \\
\hline $\begin{array}{l}\text { Medium } \\
\qquad(M)\end{array}$ & $0,021-0,081$ & $\begin{array}{l}\text { Covered granitic plutons, Colorado } \\
\text { Complex }\end{array}$ & \\
\hline $\begin{array}{l}\text { Medium to low } \\
\qquad(M L)\end{array}$ & $0,006-0,020$ & Sedimentary covers & \\
\hline $\operatorname{Low}(L)$ & $<0,006$ & $\begin{array}{l}\text { Rio Galera Complex and } \\
\text { Pindaituba Suite }\end{array}$ & \\
\hline
\end{tabular}




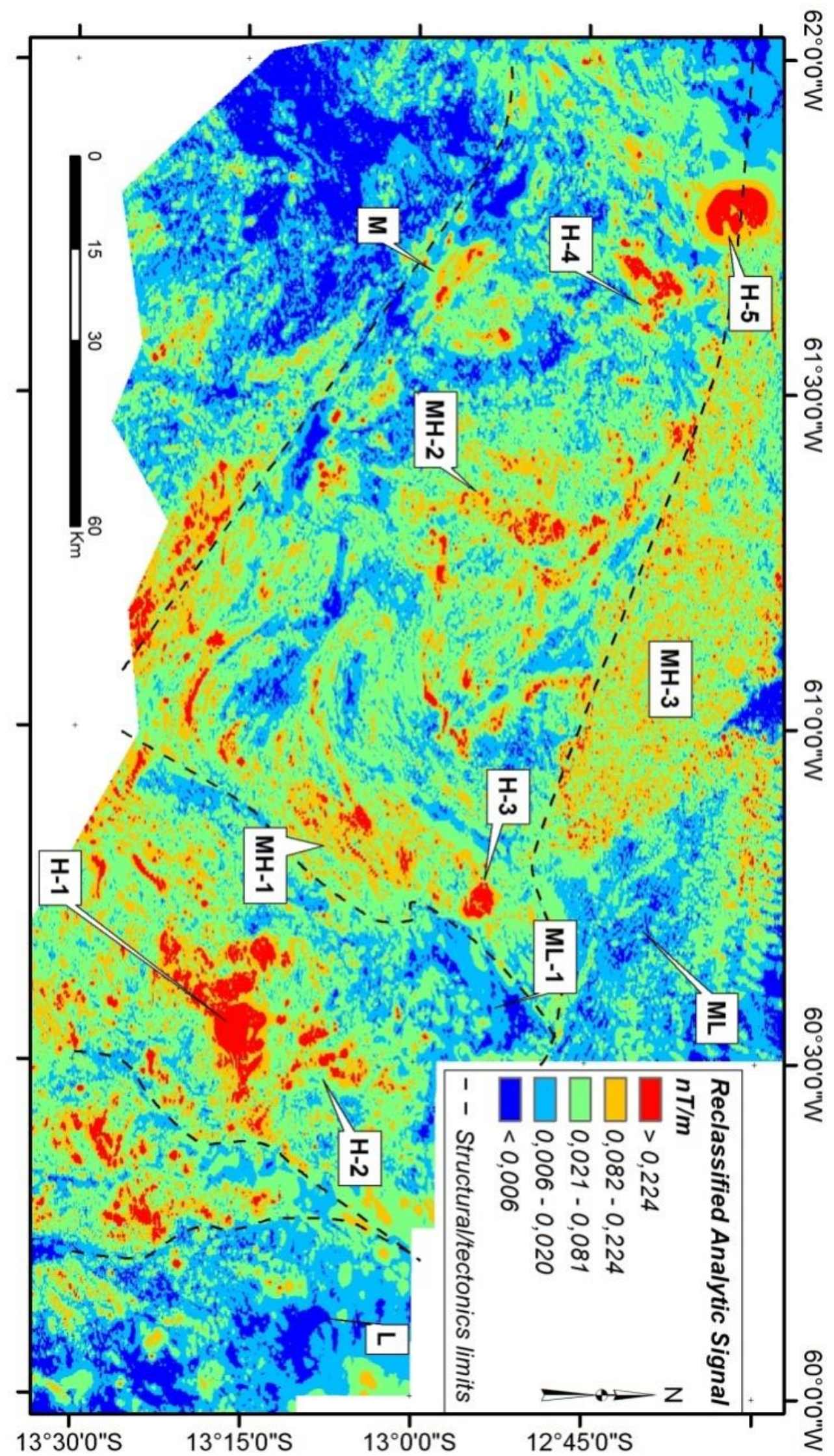

Figure 11 - Magnetic map from reclassified analytic signal amplitude. The differences between the magnetic ranges based in the reclassification highlight the textures of the magnetic domains. 
Five main domains were mapped (H-1, H-2, H-3, H-4 and H-5) on the analytic signal amplitude with high gradient (values > $0.225 \mathrm{nT} / \mathrm{m}$ ) (Fig. 11). The $\mathrm{H}-1$ domain is characterized by a local anomaly in the southeastern portion of the area. It has a round format with a diameter of approximately $7 \mathrm{~km}$, and it is represented by I-type granites of the Igarapé Enganado Intrusive Suite and ultramafic rocks of the Trincheira Complex. To the north of this anomaly, there is the H-2 domain, which shows elongated features with a NW/SE direction and extends for approximately $25 \mathrm{~km}$, represented geologically by mafic bodies and metapelitic unit of the Trincheira Complex. The H-3 domain is represented by a round anomaly with a diameter of $4 \mathrm{~km}$ located in the central region of the area and characterizes the body of the Alto Escondido Intrusive Suite. The H-4 domain presents an elongated anomaly with a NE/SW direction with an extension of $15 \mathrm{~km}$ on the major axis, with a predominance of ASA values higher than $0.225 \mathrm{nT} / \mathrm{m}$. In a geological sense, this signature represents a body of the Mafic-Ultramafic Serra Céu Azul Suite, defined as olivine-grabbro and metagabbros with potential for $\mathrm{Cr}, \mathrm{Ni}$ and $\mathrm{Cu}$ (Romanini, 1997). The H-5 domain, northwest portion of the area, has a round format with a diameter of approximately $10 \mathrm{~km}$, with a predominance of medium to high values of magnetic intensity. This anomaly it's similar to ultramafic intrusions into alkaline-carbonatite complexes.

The MH-1 domain, with a predominance of medium to high classes $(0.082-0.224$ $\mathrm{nT} / \mathrm{m}$ ), is defined by anomalies of small amplitudes of analytic signal in the middle of a rough texture, some of them with an elongated format with inflection of the magnetic structure from N50W to N35E in the center of the domain, suggesting a large crustal discontinuity defined by faults that have a predominant sinistral transcurrent component. In the south of this domain there are elongated anomalies with N50W direction that extend over $40 \mathrm{~km}$, associated to smaller anomalies, with an extension of $7 \mathrm{~km}$. The correlation with the geological units is difficult due to the Cenozoic sedimentary covers of the Guapore Basin. The outcropping basement is correlated to the Mafic-Ultramafic Trincheira Complex, where the magnetic data show the continuity of this unit below the basin sediments. The MH-2 domain has an extension of approximately $25 \mathrm{~km}$ on its major axis, aligned NNE, and has a rough magnetic texture with the higher magnetic classes concentrating on the north side of the domain, correlated to mafic granulites of the Trincheira unit. The MH-3 domain presents a characteristic texture with a predominance of anomalies of small wavelength and a magnetic intensity varying from medium to medium high, with some anomalous peaks above 0.225 $\mathrm{nT} / \mathrm{m}$. This domain extends for $100 \mathrm{~km}$ on its major axis, and is correlatable to the basalt of the Anari formation. The high frequency of the anomalies of this domain, and its 
disappearance on the upward continuation 10,000 m suggest that the magnetic sources of the domain are close to the surface.

The $\mathrm{M}$ domains represent anomalies of average magnetic intensity constituting the periphery of the greater amplitude domains. These domains show curved features imposed by deformation following a regional trend. In geologic terms, this domain is correlate to some granitic bodies and also the basement, which is represented by the Colorado Complex.

The ML and L domains are characterized as magnetic lows, with large dimensions, that occur all over the research area, and represent the geological framework with a less rough magnetic relief. On the north side, the medium to low magnetic (ML) is generally associated to the Parecis Basin. The low values of magnetic susceptibility (L domain), southeastern portion of the area, highlighted rocks of the Pindaituba Intrusive Suite and Rio Galera Complex, in the Jauru Terrane.

\subsection{Gamma spectrometric Domains}

Gamma ray spectrometry is an important source of information for soils, regoliths and geomorphologic studies. It perfectly reveals the primary lithologic information and the geochemistry of the first $30 \mathrm{~cm}$ of the ground (Wilford et al. 1997; Minty, 1997).

Elaboration of the gamma spectrometric domain map consisted in the analysis and discrimination of regions, where the radiometric response is similar in terms of textures and radioelement concentration. As final product, thirteen distinct gamma spectrometric domains were differentiated, classified in high, medium and low value according to the equivalent concentrations of potassium, thorium and uranium (Fig. 12). In order to correlate, the colors used to represent the domains were the same used on the RGB ternary map (K, eTh, eU). This evaluation made possible the correlation by analogy of the lithologic units with the map of gamma spectrometric domains (Fig. 12).

The domains with high concentration of the three radioelements highlight the external zones of the plutons of Cerejeiras and Alto Escondido, and they are also associated to schists and paragneisses of the Colorado Complex combined with granitic bodies concordant with the metamorphic foliation. In the core of the granitic plutons of Cerejeiras and Alto Escondido there are enriched zones of $\mathrm{K}$ and $\mathrm{eTh}$, although depleted of eU. The units enriched in $\mathrm{K}$ and depleted of the other radioelements, can similarly correlate to the lithotypes of the Igarapé Enganado Intrusive Suite (Fig. 12). 
The radiometric units enriched with $\mathrm{K}$ and $\mathrm{eTh}$ and moderately depleted of eU represent the units of the Parecis Basin, in the northeastern side of the area, as well as the wide drainages that transport of a large quantity of sediments of the Rio Escondido valley.

The rocks of the Colorado Complex and the Igarapé Hermes Intrusive Suite, in the sourhteastern portion of the area, are represented by radiometric units enriched in $\mathrm{K}$ and eU and depleted of eTh, corresponding to magenta shades on the RGB ternary map.

The units enriched in eTh, although varying in relation to the other elements, are attributed to the Phanerozoic covers of the Guaporé Basin, and these domains together cover the majoritiy of the area of work. Units enriched in eU and depleted of the other elements, occur in regions of the Guaporé Basin edge and are observed in some rocks of the Trincheira Complex. In this perspective, the mafic and ultramafic rocks of the Trincheira Complex, sedimentary rocks of the Parecis Basin and flooded areas on the Guapore plain reflect radiometric units depleted of the three elements.

The basalts of the Anari formation and the regolithic material, result of the weathering on this rock, present a reduction in the percentage of $\mathrm{K}$ and medium concentrations of eTh and eU. The sediments of the Fazenda Casa Branca formation also show intermediate responses of eTh and eU, though with textural signature different from the Anari formation. 


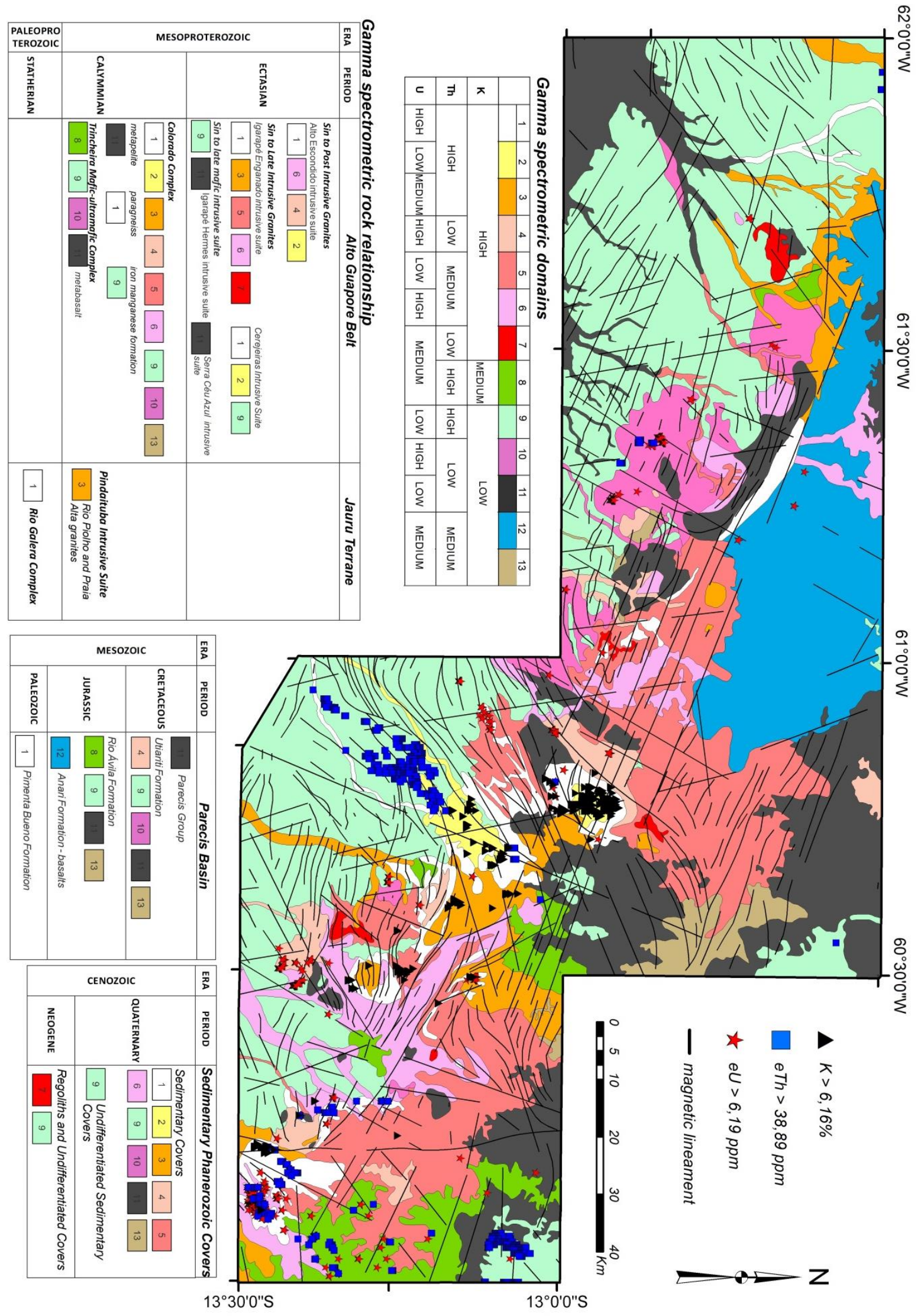

Figure 12- Gamma spectrometric domains map in the research area. Based on the interpretation of the different maps of radioelements with previous geologic data. The rocks units with their respective signature of gamma spectrometric domain are indicated. The specific anomaly of radioelement concentration were calculated from the histogram analysis of potassium, thorium and uranium values. 


\section{Isotopic and geochronological data of igneous rocks of the Alto Guaporé Belt and regional magmatism.}

The association of mafic and felsic rocks of varied nature and ages represents an important component of the Guaporé Belt, SW of the Amazonian Craton, Brazil. The emplacement and metamorphism ages of the mafic and felsic rocks, combined with the isotopic composition of $\mathrm{Nd}$, are essential to understand the tectonic evolution of the belt. Despite the "poor" precision of the Sm-Nd analysis of mafic rocks, its ages of crystallization applied to values of the initial ratio supply important information about the geological history of this Mesoproterozoic terrane (Fig. 13).

$\mathrm{U}-\mathrm{Pb}$ data on dioritic gneiss of the Colorado Complex, which have three populations of zircons grains, indicated three different ages: 1344 \pm 7 Ma (metamorphic), $1469 \pm 5 \mathrm{Ma}$ (magmatic) and 1539 $\pm 9 \mathrm{Ma}$ (inherited). The youngest is interpreted as the metamorphism age of the collisional phase (Rizzotto et al. 2013).

Sm-Nd and Sr isotopes data presented by Rizzotto et al. (2013) of the Maficultramafic Trincheira Complex gave values of initial ratio ${ }^{87} \mathrm{Sr} /{ }^{86} \mathrm{Sr}\left(\mathrm{Sr}_{\mathrm{i}}\right),{ }^{143} \mathrm{Nd} /{ }^{144} \mathrm{Nd}\left(\mathrm{Nd}_{\mathrm{i}}\right)$, $\varepsilon \operatorname{Sr}(\mathrm{T})$ and $\varepsilon \mathrm{Nd}(\mathrm{T})$, calculated based on the igneous crystallization age of $1460 \mathrm{Ma}$. The $\mathrm{Sr}_{\mathrm{i}}$ values for mafic rocks vary from 0.7002 to 0.7033 , the $\mathrm{Nd}_{\mathrm{i}}$ varies from 0.5120 to 0.5133 and positive values of $\varepsilon \mathrm{Nd}(\mathrm{T})(+2.6$ to +8.8$)$ are seen, indicating that the basaltic predecessors were derived from a source of depleted mantle. The rocks of this unit can also be correlated to the Santa Isabel Formation (southwest of Mato Grosso State) which includes amphibolites, meta-ultrabasic rocks, metabasalts, metagabbros and serpentinites (Matos et al., 2004).

Rizzotto et al. (2013) presented igneous crystallization age on mafic-ultramafic rocks of the Igarapé Hermes of $1347 \pm 8 \mathrm{Ma}$. In this work, the authors presented a Sm-Nd analysis on metagabbro, using crystallization age lower than $1100 \mathrm{Ma}$, finding a TDM age of $1.17 \mathrm{Ga}$ and $\varepsilon N d$ of +5.2 . Within this context, the Colorado mafic Intrusive Suite has crystallization ages of $1344 \pm 8$ and $1354 \pm 11 \mathrm{Ma}$ and $\varepsilon N d$ between +2.7 and +5.4 . The analysis of these data suggests a new juvenile magmatism event at the late Mesoproterozoic.

Rocks from the Igarapé Enganado Suite, from the studies of Rizzotto (2010) in zircon

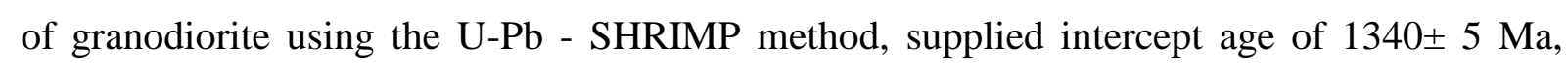
interpreted as crystallization age of the rock. Analysis of Sm-Nd isotopes gave TDM ages from 1.58 to $1.51 \mathrm{Ga}$ and $\varepsilon \mathrm{Nd}$ of +2.33 , interpreted as the time of extraction of mantle material. The suite was also dated using the U-Pb via SHRIMP by Bettencourt et al. (2010), who used samples of monzogranite and syenogranite, with concordia ages of $1340 \pm 5$ Ma. The rocks on the eastern portion of Bolivia are cronocorrelated to this unit (Litherland et al., 
1986; Boger et al., 2005), such as the San Rafael Granite of U-Pb age $1334 \pm 12 \mathrm{Ma}$ and the granites of the Alto Candeias Intrusive Suite on the western side of Rondônia.

Rizzotto (2010) determined geochronological data in the Alto Escondido Suite using the $\mathrm{U}-\mathrm{Pb}$ method on biotite syenogranite. The U-Pb data supplied an intercept age of $1340 \pm 3$ $\mathrm{Ma}$, interpreted as the age of crystallization. The $\mathrm{Sm}-\mathrm{Nd}$ method gave values of $\varepsilon \mathrm{Nd}(\mathrm{T}=1.3$ $\mathrm{Ga}$ ) of +2.35 and TDM model ages of $1.51 \mathrm{Ga}$, which indicate a primitive mantle source for these rocks. The authors also determined U-Pb data on a syenogranite with intercept age of $1337 \pm 4 \mathrm{Ma}$. The values for the Sm-Nd method were $\varepsilon \mathrm{Nd}(\mathrm{T}=1.3 \mathrm{Ga})$ of +1.55 and TDM model age of $1.58 \mathrm{Ga}$, indicating also a juvenile source with a protolith of short crustal residence. In analysis of ${ }^{40} \mathrm{Ar} /{ }^{39} \mathrm{Ar}$, Rizzotto (2010) used muscovite crystals from the aplitic leucogranite, product of metamorphism, determined ages of $1312 \pm 3 \mathrm{Ma}$, interpreted as the age of regional metamorphic cooling.

Rizzotto (2010) analyzed zircon of a sample of the Praia Alta Granite using the $\mathrm{U}-\mathrm{Pb}$ LA-MC-ICP-MS method finding ages of $1432 \pm 13$ Ma, interpreted as ages of rock crystallization. Ages of Rizzotto et al. (2013) in zircon of biotite syenogranite using the U-PbLA-MC-ICP-MS method, included imaging via cathodoluminescence highlighting crystals with prismatic habits and 100 to $200 \mathrm{~mm}$ in size, and metamorphic zoning pattern. Nevertheless, the contents of $U$ and Th supplied median values, creating ratios $\mathrm{Th} / \mathrm{U}$ between 0.13 and 0.59 , that suggest grains of igneous origin. SHRIMP analysis in zircon of this rock gave average ages of the ratio ${ }^{207} \mathrm{~Pb} /{ }^{206} \mathrm{~Pb}$ of $1436 \pm 7 \mathrm{Ma}$, interpreted as crystallization age. The second sample analyzed, syenogranite (the same rock dated by Rizzotto, 2010), showed large well-faceted zircon crystals. The U-Pb analysis on zircon by LA-MC-ICP-MS, generated data with ratios $\mathrm{Th} / \mathrm{U}$ varying between 0.24 and 0.42 , indicating crystals with magmatic origin, and concordia ages of $1426 \pm 5 \mathrm{Ma}$, interpreted as the igneous crystallization age of the rock.

Ruiz (2005) reported $\mathrm{U}-\mathrm{Pb}$ geochronological data from biotite monzogranite of this unit (sample from the Morro Sem Boné Sheet) on yellowish, prismatic, medium size zircon crystals. Ages of upper intercept of $1423 \pm 11$ Ma were obtained, interpreted as the igneous crystallization age of the rock. The isotopic Sm-Nd data of this rock supplied by Ruiz (2005) present TDM model ages of $2.0 \mathrm{Ga}$, that according to the author, indicates that there was mantellic differentiation at the beginning of the Orosirian. A positive value was obtained for the pattern $\varepsilon \mathrm{Nd}(\mathrm{t})$ of 0.91 , which indicates a predominant mantellic source, although with crustal participation for the protolith of this rock. 


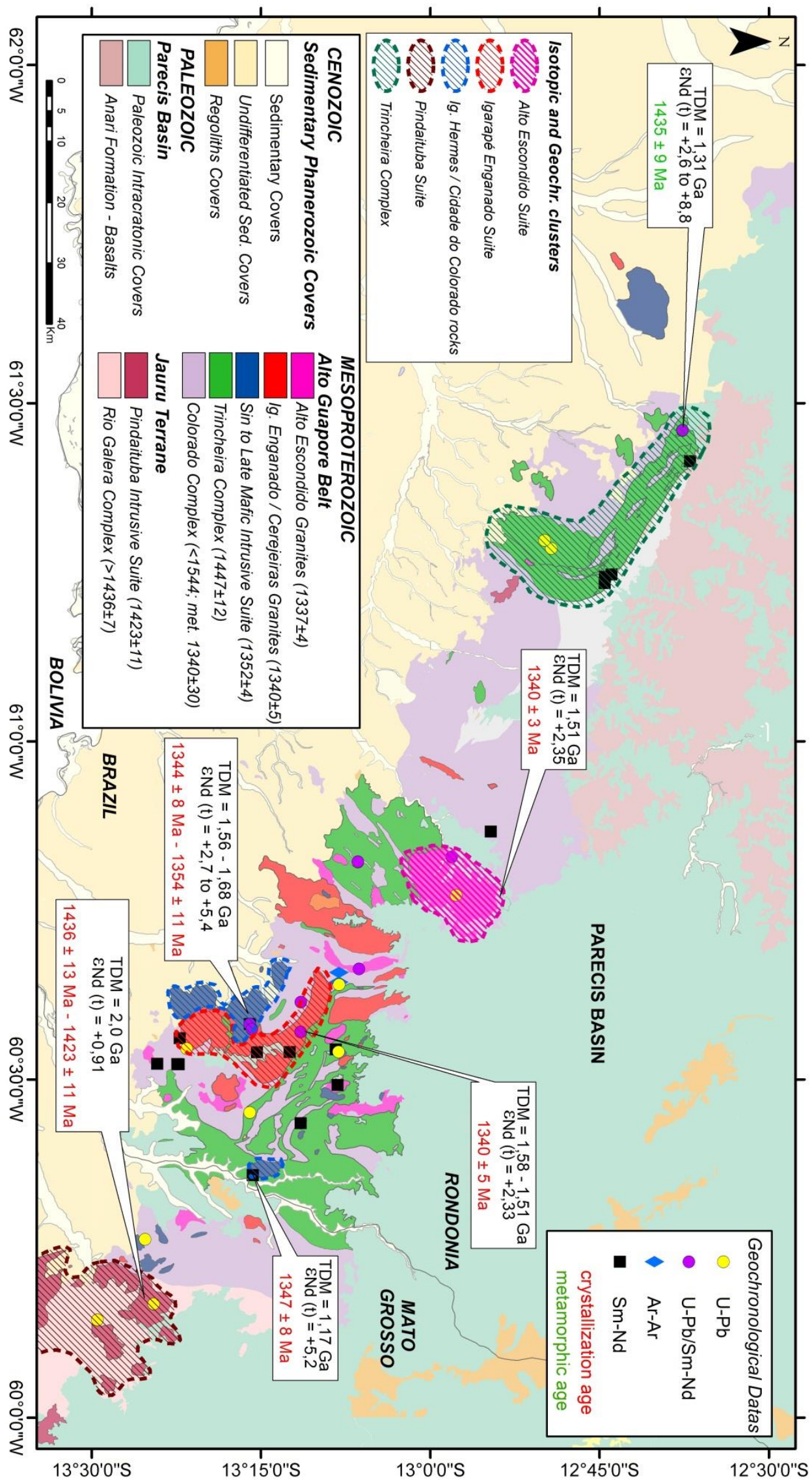

Figure 13- Geochronological data source compiled: Scandolara, 2006; Rizzotto, 2010; Rizzotto et al., 2013; Ruiz, 2005. 


\section{Discussion and conclusions}

The airborne geophysical data show that the southeastern of the State of Rondônia carries a complex tectonic history with distinct events of deformation superimposed. The Phanerozoic sedimentary beds, layers (Parecis and Guaporé basins) cover great part of the region, making the mapping of important geological features of the basement difficult. In this sense, it is essential to integrate airborne geophysical data as well as data collected in field for the advancement in the geological understanding of the region.

The analysis of the magnetic data allowed the individualization of crustal segments with distinct magnetic signatures, aiding in the tectonic understanding of the region. The extraction of the magnetic lineaments allowed to characterize the structural framework of the region. The signatures of magnetic structures of deep source show two main trends, N50W and N35E. These lineaments probably represent large crustal discontinuities related to the agglutination of terranes with distinct magnetic signatures, and are associated to the limits between the Alto Guaporé Belt and the Paraguá and Jauru terranes. The map of pseudogravity of the area emphasizes the presence of these deep discontinuities. The shallower magnetic lineaments, extracted from the ASA, were differentiated temporally through the cross cutting relation for the upward continuation maps, which enabled the identification of three distinct structural domains in the region. The oldest lineaments related to the D1 pattern, are probably associated to the Rondoniana-San Ignacio orogeny between the Paraguá Terrane and the Amazonian proto-craton, described by Loewy et al. (2004), Boger et al. (2005) and Rizzoto and Hartmann (2012). The lineaments related to the D2 domain are the less expressive in the area of research and follow the same structural trend of the Rio Vermelho lineament (Pindaiatuba Intrusive Suite) in the Jauru Terrane, northwest of Mato Grosso State, associated to the Sunsás orogeny. The D3 domain is characterized by large straight magnetic lineaments related to brittle structures, which used the crustal anisotropy generated during the D1 and D2 events. These structures were possibly activated during the opening of the Parecis Basin in the Paleozoic.

The integration of the radiometric data allowed the elaboration of the gamma spectrometric domains map, which enabled the discrimination of the Phanerozoic sedimentary basins and the detailing of the rocks that make up the Proterozoic basement. From this analysis it is possible to observe the influence of sedimentary covers of the Guapore Basin, on the southwestern portion of the research area, and of rocks of the Parecis Basin, on the northern and northeastern portions. Thus, rocks of the basement are limited to a narrow zone of norhtwest/southeast direction, partially concordant with its internal structure. Later on, it 
was verified that these radiometric signatures had a correlation with the geologic units mapped, or with hydrographic features present in the region.

The Sm-Nd isotopic data of the mafic and felsic rocks of the region under study are similar and suggest a unique tectonic domain, whose crustal history is related to the evolution of an island arc (1460 - $1340 \mathrm{Ma})$, except for the mafic-ultramafic Igarapé Hermes rocks with $\mathrm{TDM}$ values of $1.17 \mathrm{Ga}$ and $\varepsilon N d$ of +5.2 . Strongly positives values of $\varepsilon N d(\mathrm{~T})(+2$ to +9$)$ for the rocks of the Trincheira Complex are compatible with the absence of crustal contamination on the original magma, fact coherent with the oceanic environment in which the mafic basal rocks are probably originated related to a back-arc environment. The intermediate to acid rocks of calc-alkaline composition, Igarapé Enganado and Rio Escondido suites, showed sources with a longer period of crustal residence (TDM 1.51 to $1.63 \mathrm{Ga}$ ) and values of $\varepsilon \mathrm{Nd}$ of +1.5 to +2.33 suggesting a subordinated contribution of crustal material. On the other hand, the Praia Alta Granite, with a crystallization age of $1423 \pm 11$ Ma shows a TDM model age of 2.0 $\mathrm{Ga}$ and $\varepsilon N d(\mathrm{t})$ pattern of 0.91 , which indicates a mantle source, although with an important crustal participation for the protolith of this rock.

The geodynamic history and geologic architecture are important parameters for the definition of mineral systems and development of models of target for mineral exploration in regional and local scales. The application of this kind of procedure is the first step for the understanding of the mineralizing processes. In this sense, the results of the study can be summarized as follows:

1. The limit of the Alto Guaporé Belt with the Jauru Terrane is well delimited by both gravimetry and magnetometry, suggesting a distinct geotectonic evolution;

2. Sm-Nd isotopic chemistry data indicate different TDM ages and $\varepsilon N d(t)$ for the rocks of the magmatic arc, Trincheira Complex and the rocks of the Jauru Terrane;

3. The Alto Guaporé Belt structures indicate a variation from NW to NE, pointing a more complex kinematic;

4. Even though the integration of airborne geophysical data shows different structural domains, the isotopic geochemistry shows the same crustal evolution for the Alto Guaporé Belt. 


\section{Acknowledgement}

We thank the Brazilian Geological Survey (CPRM) for the access to the airborne geophysical, geological and geochronological data, specially the geologists Elias Martins and Gulherme Ferreira for the support of the field work. Special thanks the CPRM for the financial support (process no. ATA1135/memo101/SEGER/2014), and the University of Brasília for the technical support and permission of laboratory use, and the geologist Bianca Takenaka for help with geochronological data. A. M. Silva thanks the Conselho Nacional de Desenvolvimento Científico e Tecnológico (CNPq) for her research grant.

\section{References}

Bahia, R.B.C., Martins-Neto, M.A., Barbosa, M.S.C., Pedreira, A.J., 2007. Análise da evolução tectonossedimentar da Bacia dos Parecis através de métodos potenciais. Brazilian Journal of Geology, 37(4), 639-649.(in Portuguese).

Bahia, R.B.C., Pedreira, A.J., 1998. Estratigrafia, sedimentação e tectônica da cobertura fanerozóica do estado de RO. In: XL Congresso Brasileiro de Geologia, Belo Horizonte, Anais, pp. 102. (in Portuguese).

Baranov, V., 1957. A new method for interpretation of aeromagnetic maps: pseudogravimetric anomalies. Geophysics, 22(2), 359-382.

Baranov, V., Naudy, H., 1964. Numerical calculation of the formula of reduction to the magnetic pole (airborne). Geophysies, 29, 67-79.

Bettencourt, J.S., Leite, W.B., Ruiz, A.S., Matos, R., Payolla, B.L., Tosdal, R.M., 2010. The Rondonian-San Ignacio Province in the SW Amazonian Craton: an overview. Journal of South American Earth Sciences, 29(1), 28-46.

Blakely, R.J., 1996. Potential theory in gravity and magnetic applications. Cambridge University Press, Cambridge, UK. 441p.

Blakely, R.J., Simpson, R.W.,1986. Approximating edges of source bodies from magnetic or gravity anomalies: Geophysics, 51, 1494-1498. 
Boger, S.D., Raetz, M., Giles, D., Etchart, E., Fanning, M.C., 2005. U-Pb age data from the Sunsas region of Eastern Bolivia, evidence for the allochtonous origin of the Paraguá Block. Precambrian Research 139 (3-4), 121-146.

Briggs, I.C., 1974. Machine contouring using minimum curvature. Geophysics, 39(1), 39-48.

Cooper, G.R.J., Cowan, D.R., 2006. Enhancing potential field data using filters based on the local phase. Computers\&Geosciences, 32(10), 1585-1591.

Cordani, R., Shukowsky, W., 2009. Magnetização remanescente: um parâmetro crucial para a interpretação e modelamento de anomalias magnéticas em território brasileiro. Revista Brasileira de Geofísica, 27(4), 659-667. (in Portuguese).

Cordani, U.G., Brito Neves, B.B., 1982. The geologic evolution of South América during the Archean and Early Proterozoic. Revista Brasileira de Geologia, 12 (1-3), 78-88.

Cordani, U.G., Tassinari, C.C.G., Teixeira, W., Basei, M.A.S., Kawashita, K., 1979. Evolução tectônica da Amazônia com base em dados geocronológicos. In: 2nd Congresso Geológico Chileno, Actas, Arica, Chile, 137-148.

Cordani, U.G., Teixeira, W., 2007. Proterozoic accretionary belts in the Amazonian Craton.In: Hatcher, R.D., Jr., Carlson, M.P., McBride, J.H., MartínezCatalán, J.R. (Eds.), 4-D Framework of Continental Crust. GeologicalSocietyofAmericaMemoir, 200, pp. 297-320.

CPRM - Serviço Geológico do Brasil., 2006. Projeto Aerogeofísico Sudeste de Rondônia: relatório final de levantamento e processamento dos dados magnetométricos e gamaespectrométricos. Rio de Janeiro: Lasa Engenharia e Prospecções; Prospectors Aerolevantamentos e Sistemas,.27v. (in Portuguese).

Fairhead, J.D., Williams, S.E., 2006. Evaluating normalised magnetic derivatives for structural mapping. SEG 2006. New Orleans Extended Abstract.

Fedi, M., Florio G., 2001. Detection of potential fields source boundaries by enhanced horizontal derivative method. Geophysical prospecting 49.(1), 40-58. 
Geosoft Inc., 2011a. MAGMAP Filtering.Technical Documentation. Tutorial Geosoft Inc.,

Canada. <www.geosoft.com/support/downloads/technical-documentation> (accessed 18.05.13).

GETECH Group. 2007. Advanced Processing and Interpretation of Gravity and Magnetic Data.(Geophysical Exploration Technology). Kitson House Elmete Hall Leeds, UK. 22p.

Gunn, P. J., Maidment, D., Milligan, P.R. 1997ª Interpreting aeromagnetic data in areas of limited outcrops. AGSO-Journal of Australian Geology and Geophysics. 17(2), 175-185.

Gunn, P.J., Milligan, P., Mackey, T., Liu, S., Murray, A., Maidment, D., Haren, R. $1997^{\text {b }}$ Geophysical mapping using the national airborne and gravity datasets: an example focusing on Broken Hill. AGSO-Journal of Australian Geology and Geophysics. 17(2), 127-136.

Hsu, S.K., Sibuet, J. C., Shyu., C.T. 1996. High-resolution detection of geological boundaries from potential-field anomalies: An enhanced analytic signal technique: Geophysics, 61, 373386.

IAEA - International Atomic Energy Agency, 2003. Nuclear Fuel Cycle and Materials Section. Guidelines for radioelement mapping using gamma ray spectrometry data. International Atomic Energy Agency.

Jaques, A.L., Wellman, P., Whitaker, A., Wyborn, D. 1997. High resolution geophysics in modern geological mapping AGSO Journal of Australian Geology and Geophysics.17(2), 159-173. 1997.

Kroonenberg, S.B. 1982. A Grenvillian Granulite Belt in the Colombian Andes and its relation to the Guiana Shield. GeologieenMijnbouw, 61, 325-333.

Litherland, M., Annels, R.N., Appleton, J.D., Berrange, J.P., Bloomfield, K., Burton, C.C.J., Darbyshire, D.P.F., Fletcher, C.J.N., Hawkins, M.P., Klinck, B.A., Llanos, A., Mitchell, W.I., O'Connor, E.A., Pitfield, P.E.J., Power, G., Weeb, B.C. 1986. The Geology and Mineral Resources of the Bolivian Precambrian Shield. London, Brit. Geol. Surv. 153 p. (Overseas Memoir 9) Her Majesty’s Stationery Office. 140 p. 
Litherland, M., Annells, R.N., Darbyshire, D.P.F., Fletcher, C.J.N., Hawkins, M.P., Klinck, B.A., Mitchell, W.I., O’Connor, E.A., Pitfield, P.E.J., Power, G., Webb, B.C., 1989. The Proterozoic of eastern Bolivia and its relationship to the Andean mobile belt. Precambrian Research 43, 157-174.

Loewy, S.L., Connelly, J.N. and Dalziel, I.W.D., 2004. An orphaned basement block: the Arequipa-Antofalla Basement of the central Andean margin of South America. GSA Bull. $116(1 / 2), 171-187$.

MacLeod, I.N., Vieira, S., Chaves, A.C. 1993.Analytic signal and reduction-to-the-pole in the interpretation of total magnetic field data at low magnetic latitudes. In: 3rd International Congress of the Brazilian Geophysical Society. Rio de Janeiro, p.830-835

Matos, J.B., Schorscher, J.H.D., Geraldes, M.C., Sousa, M.Z.A., Ruiz, A.S., 2004. Petrografia, geoquímica e geocronologia das rochas do Orógeno Rio Alegre, Mato Grosso: um registro de crosta oceânica mesoproterozóica no SW do Cráton Amazônico. Geologia USP, Série Científica 4, 75-90 (in Portuguese).

Mariani, P., Braitenberg, C., Ussami, N., 2013. Explaining the thick crust in Paraná basin, Brazil, with satellite GOCE gravity observations. Journal of South American Earth Sciences, Volume 45, Pages 209-223, ISSN 0895-9811.

van der Meijde, M. J., Assumpção, J.M. 2013. Gravity derived Moho for South America, Tectonophysics, Volume 609, Pages 456-467.

Metelka, V., Baratouxa, L., Naba, S., Jessell, M.W. 2011. A geophysically constrained lithostructural analysis of the Eburnean greenstone belts and associated granitoid domains, Burkina Faso, West Africa. Precambrian Research, v. 190, pp. 48-69.

Mikhailov, V., Tikhotsky, S., Diament, M., Panet, I., Ballu, V., 2004. Can tectonic processes be recovered from new gravity satellite data? Earth and Planetary Science Letters, 228, 3-4, 281-297. 
Miller, H.G., Singh, V.,1994. Potential field tilt a new concept for location of potential field sources. Journal of Applied Geophysics, v. 32, p. 213-217.

Milligan P.R., Gunn, P.J.1997. Enhancement and presentation of airborne geophysical data.Journal of Australian Geology and Geophysics 17(2), 63-75.

Minty, B.R.S., 1991. Simple micro-levelling for aeromagnetic data. Exploration Geophysics, 22(4), 591-592.

Minty, B.R.S., 1997. Fundamentals of airborne gamma-ray spectrometry. Journal of Australian Geology \& Geophysics 17 (2), 39-50.

Mishra, D.C., Arora, K., Tiwari, V.M., 2004. Gravity anomalies and associated tectonic features over the Indian Peninsular Shield and adjoining ocean basins, Tectonophysics, 379, $1-4,13,61-76$.

Murthy, I.V.R., 1985, Magnetic interpretation of dike anomalies using derivatives: PAGEOPH, 123, 232-238.

Nabighian, M.N., 1972. The analytic signal of two-dimensional magnetic bodies with polygonal cross-section: its properties and use for automated anomaly interpretation. Geophysics, v. 37, n. 3, p. 507-517.

Nabighian, M.N. 1974. Additional comments on the analytic signal of two dimensional magnetic bodies with polygonal cross-section: Geophysics 39, 85-92.

Nabighian, M.N. 1984. Toward a three-dimensional automatic interpretation of potential field data via generalized Hilbert transforms: Fundamental relation Geophysics, 49, 957-966.

Nunes, N.S.V., 2000. Geologia e resultados prospectivos das áreas Morro do Leme e Morro Sem Boné/Mato Grosso. - Goiânia: CPRM.1v. : Il; mapas (Informe de Recursos Minerais. Série Metais do Grupo da Platina e Associados, $n^{\circ}$ 19) Projeto Platina e Associados. (in Portuguese). 
Oliveira, C.E.S.; Prado, E.M.G.; Silva, G.F.; Graça, M.C., 2015. Carta geofísica-geológica do Bloco Sudeste, áreas Rondônia e Acre. Projeto Províncias Metalogenéticas do Brasil. Porto Velho: CPRM,.il. color. Escala 1:250.000. Projeto Províncias Metalogenéticas do Brasil: áreas Rondônia e Acre. (in Portuguese).

Phillips, J.D., 2000. Locating magnetic contacts: a comparison of the horizontal gradient, analytic signal, and local wavenumber methods. In 70th Annual International Meeting, SEG, Expanded Abstracts (pp. 402-405).

Pimentel, M. M., Fuck, R.A., 1992. Neoproterozoic crustal accretion in Central Brazil. Geology, 20(4), 375-379.

Pinto Filho, F.P., Freitas, A.F., Melo, C.F., Romanini, S.J., 1977. Projeto Sudeste de Rondônia, vol. 1. CPRM/DNPM Final Report, Porto Velho. (in Portuguese).

Pires, A.C.B., 1995. Identificação geofísica de áreas de alteração hidrotermal, CrixásGuarinos, Goiás. Revista Brasileira de Geociências, v. 25, n. 1, p. 61-68. (in Portuguese).

Pratt, D.A., Shi, Z., 2004. Na Improved Pseudo-gravity Magnetic Transform Technique for Investigation of Deep Magnetic Source Rocks. Geophisical Conference and Exhibition, ASEG 17, Sydney.

Priem, H.N.A., Bon, E.H., Verdurmen, E.A.T., Bettencourt, J.S., 1989. Rb-Sr chronology of Precambrian crustal evolution in Rondonia (western margin Brasilian craton). Journal of South American Earth Sciences 2, 163-170.

Quadros, M.L.E.S.; Rizzotto, G.J.,2007. Geologia e recursos minerais do Estado de Rondônia: texto explicativo do mapa geológico e de recursos minerais do Estado de Rondônia. Escala 1:1.000.000. Porto Velho: CPRM,. 116 p. il. Programa Geologia do Brasil (in Portuguese).

Rajagopalan, S., 2003.Analytic signal vs. reduction to pole: solutions for low magnetic latitudes. Exploration Geophysics 34 (4), pp. 257-262. 
Rao, D.A., Babu, H.V., Narayan, P.V., 1981. Interpretation of magnetic anomalies due to dikes: The complex gradient method: Geophysics, 46, 1572-1578.

Reeves, C., 2005. Aeromagnetic surveys: principles, practice and interpretation. Delft: Geosoft,. 155 p. il.

Rizzotto, G. J., 2010. Geologia e recursos minerais da Folha Pimenteiras SD.20-X-D: texto explicativo do mapa geológico e de recursos minerais da Folha Pimenteiras. Porto Velho: CPRM, 136 p. (in Portuguese).

Rizzotto, G. J., 2014. Geologia e recursos minerais da Folha Vilhena (SD.20-X-B): Sistema de Informações Geográficas-SIG: texto explicativo do mapa geológico e de recursos minerais da Folha Vilhena, escala 1:250.000. Porto Velho: CPRM, 175 p. il., color. Programa Geologia do Brasil (PGB). (in Portuguese).

Rizzotto, G.J., Bettencourt, J.S., Teixeira, W., Pacca, I.I.G., D’Agrella, M.S., Vasconcelos, P., Basei, M.A.S., 2002. Geologia e geocronologia da Suíte Metamórfica Colorado e suas encaixantes, SE de Rondônia: implicações para a evolução mesoproterozóica do SW do Cráton Amazônico. Geologia USP, Série Científica 2, 41-55. (in Portuguese).

Rizzotto, G.J., Hartmann, L.A., 2012. Geological and geochemical evolution of the Trincheira Complex, a Mesoproterozoic ophiolite in the southwestern Amazon Craton, Brazil.Lithos, v. 148, n. 1, p. 277-295.

Rizzotto, G.J., Santos, J.O.S., Hartmann, L.A., Tohver, E., Pimentel, M.M., McNaughton, N.J., 2013. The Mesoproterozoic Guaporé suture in the SW Amazonian Craton: geotectonic implications based on field geology, zircon geochronology and $\mathrm{Nd}-\mathrm{Sr}$ isotope geochemistry. Journal of South American Earth Sciences, v.48, p. 271-295.

Roest, W.R., Verhoef, J., Pilkington, M. 1992. Magnetic interpretation using the 3-D analytic signal.Geophysics, 57(1): 116-125.

Romanini, S.J. 1997. Mapa geológico preliminar da Serra Céu Azul/RO: prospecção geoquímica e síntese geológico-metalogenética. Porto Alegre: CPRM. (Informe de Recursos 
Minerais. Série Metais do Grupo da Platina e Associados, 03). Programa Nacional de Prospecção de Metais do Grupo da Platina.

Romanini, S.J., 2000. Geologia e prospecção geoquímica/aluvionar da área Corumbiara/Chupinguaia-Rondônia. Porto Alegre: CPRM (Informe de Recursos Minerais. Série Metais do Grupo da Platina e Associados, 06).

Ruiz, A.S., 2005. Evolução geológica do sudoeste do Cráton Amazônico, região limítrofe Brasil-Bolívia, Mato Grosso. Universidade Estadual de São Paulo, Rio Claro, São Paulo, Brazil. (in Portuguese).

Saes, G.S., Fragoso Cesar, A.R.S. 1996. Acresção de terrenos mesoproterozóicos no SW da Amazônia. In: SBG, Cong. Bras.Geol., 39, Salvador, Boletim de Resumos Expandidos, (1) $348 p$ (in Portuguese).

Salem, A., Williams, S., Fairhead, D., Smith, R., Ravat, D., 2007. Interpretation of magnetic data using tilt-angle derivatives. Geophysics, 73(1), L1-L10.

Santos, J.O.S., Hartmann, L.A., Gaudette, H.E., Groves, D.I., McNaughton, N., Fletcher, I.R., 2000. A new understanding of the provinces of the Amazon Craton based on integration of field mapping and U-Pb and Sm-Nd geochronology. Gondwana Research 3 (4), 453-488.

Santos, J.O.S., Rizzotto, G.J., Potter, P.E., McNaughton, N.J., Matos, R.S., Hartmann, L.A., Chemale, F., Quadros, M.E.S. 2008. Age and autochthonous evolution of the Sunsás Orogen in West Amazon Craton based on mapping and $\mathrm{U}-\mathrm{Pb}$ geochronology. Precambriam Research $165,120-152$.

Saunders, D.F., Burson, R.K., Branch, F.J., Thompson, K.C. 1993. Relation of thoriumnormalized surface and aerial radiometric data to subsurface petroleum accumulations.Geophysics, v.58:1417- 1427.

Scandolara, J.E., 2006. Geologia e evolução do terreno Jamari, embasamento da faixa Sunsás/Aguapei, centro-leste de Rondônia, sudoeste do Cráton Amazônico. Universidade de Brasília, Brasília, Brazil (in Portuguese). 
Scandolara, J.E., Amorim, J.L. 1999. A faixa móvel Guaporé, sua definição e inserção no contexto geotectônico do SW do Cráton Amazônico. VI Simposium Nacional de Estudos Tectônicos (SNET) p. 24-27 (in Portuguese).

Scandolara, J.E., Rizzotto, G.J., Bahia, R.B.C., Quadros, M.L.E.S., Amorim, J.L., Dall'Igna, L.G., 1999. Geologia e Recursos Minerais do Estado de Rondônia: texto explicativo e mapa geológico na escala 1:1.000.000. Programa Levantamentos Geológicos Básicos do Brasil. CPRM-Serviço Geológico do Brasil, Brasília, Brasil (in Portuguese).

Schobbenhaus, C., 2001. Geological map of South America, scale 1:5000000, CGMWCPRM-DNPM-UNESCO, Brasília, Brazil

Spector, A., Grant, F.S., 1970. Statistical model for interpreting aeromagnetric data Geophysics, 35 (2), pp. 293-302.

Stewart, J.R., Betts P.G. 2010. Implications for Proterozoic plate margin evolution from geophysical analysis and crustal-scale modeling within the western Gawler Craton, Australia. Tectonophysics, 483: 151-177.

Tassinari, C.C.G. 1981. Evolução geotectônica da província Rio Negro-Juruema na região Amazônica. Instituto de Geociências, Universidade de São Paulo, São Paulo, Dissertação de Mestrado, 2v. 99 p. (in Portuguese).

Tassinari, C.C.G., Bettencourt, J.S., Geraldes, M.C., Macambira, M.J.B., Lafon. J.M. 2000. The Amazonian Craton. In: Cordani, U.G., Milani, E.J., ThomazFilho, A., Campos, D.A. (Eds.), Tectonic evolution of South America. 31st InternationalGeologicalCongress, Rio de Janeiro, Brazil, pp. 41-95.

Tassinari, C.C.G., Cordani, U.G., Nutman, A.P., Van Schmus, W.R., Bettencourt, J.S., Taylor, P.N., 1996. Geochronological systematics on basement rocks from the Rio NegroJuruena Province (Amazonian Craton) and tectonic implications.International Geology Review 38, 161-175. 
Tassinari, C.C.G., Macambira, M.J.B., 1999. Geochronological provinces of the Amazonian Craton.Episodes 22, 174-182.

Tassinari, C.C.G., Siga Jr., O., Teixeira, W., 1984. Épocas metalogenéticas relacionadas à granitogênese do Cráton Amazônico. In: Cong. Brás. Geol., 33, 1984, Rio de Janeiro. Anais. 12v. il. v.6., p. 2963-2977. (in Portuguese).

Teixeira, W. Tassinari, C.C.G., 1984. Caracterização geocronológica da Província Rondoniana e suas implicações geotectônicas. In: 2nd Symposium Amazônico, Actas, Manaus. Amazonas, Brazil, pp. 75-86 (in Portuguese).

Teixeira, W.,Tassinari, C.C.G., Cordani, U.G., Kawashita, K., 1989. A review of the geochronology of the Amazonian Craton: tectonic implications. PrecambrianResearch 42, 213-227.

Thompson, D.T., 1982, EULDPH: A new technique for making computer-assisted depth estimates from magnetic data: Geophysics, 47:31-37.

Verduzco, B., Fairhead, J.D., Green, C.M., MacKenzie, C., 2004. New insights into magnetic derivatives for structural mapping. The Leading Edge, 23(2), 116-119.

Wijins, C., Perez, C., Kowalezyk, P., 2005. Theta map: Edge Detection in Magnetic Data. Geophysics, 70, pp. L39-L43

Wilford, J.R., Bierwirth, P.N., Craig, M.A., 1997. Application of airborne gamma-ray spectrometry in soil/regolith mapping and applied geomorphology. AGSO Journal of Australian Geology \& Geophysics, 17(2), 201-2016. 
4. Conclusões 


\section{CONCLUSÕES}

Os dados aerogeofísicos mostram que o sudeste do Estado de Rondônia possui uma história tectônica complexa com distintos eventos de deformação superimpostos. As bacias sedimentares fanerozóicas (Bacia do Parecis, Bacia do Guaporé) recobrem grande parte da região, dificultando o mapeamento de importantes feições geológicas do embasamento. Neste sentido, é determinante a integração dos dados aerogeofísicos e dos dados coletados em campo para o avanço no entendimento geológico da região.

A análise dos dados magnéticos permitiu a individualização de segmentos crustais com assinaturas magnéticas distintas, auxiliando o entendimento tectônico da região. A extração dos lineamentos magnéticos possibilitou a caracterização do arcabouço estrutural da região. As assinaturas de estruturas magnéticas de fonte profunda encontram-se em duas direções principais, N50W e N35E. Estes lineamentos provavelmente representam grandes descontinuidades crustais, relacionadas à aglutinação de terrenos com assinaturas magnéticas distintas, e estão associados aos limites entre a Faixa Alto Guaporé e os terrenos Paraguá e Jauru. O mapa de pseudogravidade da área reforça a presença destas descontinuidades profundas. Os lineamentos magnéticos mais rasos, extraídos da ASA, foram diferenciados temporalmente por meio das relações de corte, o que possibilitou a identificação de três eventos de deformação na região. Os lineamentos mais antigos, relacionados ao evento D1, provavelmente, estão associados com a orogenia mesoproterozoica entre o Terreno Paraguá e o proto-cráton Amazônico, descrita por Loewy et al. (2004); Boger et al. (2005) e Rizzoto et al. (2013). Os lineamentos relacionados ao evento D2 são os de menor expressão na área de estudo e seguem o mesmo trend estrutural do lineamento Rio Vermelho (Suíte Intrusiva Pindaituba) no Terreno Jauru, noroeste do Mato Grosso, associado à orogenia Sunsás. A estruturação D3 é caracterizada por grandes lineamentos magnéticos retilíneos relacionados a estruturas rúpteis, que aproveitaram a anisotropia crustal gerada nos eventos D1 e D2. Estas estruturas possivelmente foram ativadas durante a abertura da Bacia dos Parecis no Mesozoico.

A integração dos dados radiométricos permitiu elaborar o mapa de domínios gamaespectrométricos, e a individualização das bacias sedimentares fanerozóicas e 
o detalhamento das rochas do embasamento mesoproterozoico, como a separação dos principais conjuntos de rochas que afloram na área de pesquisa. A partir desta análise é possível notar a influência de coberturas sedimentares da Bacia do Guaporé, na porção sudoeste da área de trabalho e de rochas da Bacia do Parecis, nas porções norte e nordeste. Assim, as rochas do embasamento estão condicionadas a uma estreita faixa de direção noroeste/sudeste, concordante parcialmente com a tendência direcional de estruturação. Verificou-se posteriormente que as assinaturas radiométricas possuíam correlação com as unidades geológicas mapeadas, ou com feições hidrográficas presentes na região.

De acordo com os dados isotópicos $\mathrm{Sm}-\mathrm{Nd}$ nas rochas máficas e félsicas dos trabalhos de Scandolara (2006); Rizzotto (2010); Rizzotto et al. (2013) e Ruiz (2005). Estes dados sugerem um único domínio, cuja história crustal tem relação com a evolução de um arco de ilhas (1460 - 1340 Ma), exceção das rochas máficoultramáficas Igarapé Hermes com valores TDM de 1.17 Ga e $\varepsilon N d$ de +5.2. Valores acentuadamente positivos de $\varepsilon N d(T)(+2$ a +9$)$ para as rochas do Complexo Trincheira são compatíveis com ausência de contaminação crustal no magma original, situação coerente com ambiente oceânico em que as rochas máficas basais tem natureza provavelmente relacionada a ambiente de back-arc. As rochas intermediárias a ácidas de composição cálcio-alcalina, suítes Igarapé Enganado e Rio Escondido, mostram fontes com um período maior de residência crustal (TDM 1.51 a $1.63 \mathrm{Ga})$ e valores de $\varepsilon N d$ de +1.5 a +2.33 , sugerindo contribuição muito subordinada de material crustal. Por outro lado, o Granito Praia Alta, com idade de

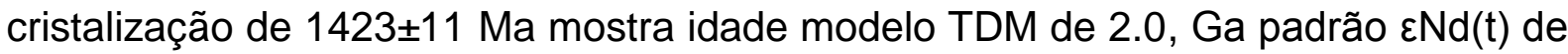
0.91, que indica fonte predominantemente mantélica, porém com participação crustal para o protólito desta rocha.

A integração dos diferentes produtos gerados a partir da aerogeofísica possibilitou avanço no entendimento estrutural e tectônico da área de estudo, dificultado pela extensa cobertura sedimentar fanerozoica que recobre o embasamento da região, além de auxiliar no refinamento das unidades geológicas cartografadas em campo. Esta integração facilita a caracterização dos padrões geológicos/geofísicos na região mapeada, que podem ser utilizados para sugerir alvos de interesse econômico. 
5. REFERÊnCIAS BIBLIOGRÁFICAS 


\section{REFERÊNCIAS BIBLIOGRÁFICAS}

BETTENCOURT, J. S. et al. The Rondonian-San Ignacio Province in the SW Amazonian Craton: an overview. Journal of South American Earth Sciences, v. 29, p. 28-46, 2010.

BOGER SD, RAETZ M, GILES D, ETCHART E AND FANNING CM. 2005. U-Pb age 170 data from the Sunsas region of eastern Bolivia, evidence for the allochtonous origin of the Paraguá Block. Precam Res 139: 121-146.

CORDANI, U. G. et al. Evolução tectônica da Amazônia com base nos dados geocronológicos. In: CONGRESO GEOLOGICO CHILENO, 2., 1979, Chile. Actas. Chile, 1979. p. $137-148$.

CORDANI, U. G.; NEVES, B. B. de B. The geologic evolution of south America during the archean and early preterozoic. Revista Brasileira de Geociências, v. 12, n. 1-3, p. 78-88, 1982.

CORDANI, U. G.; TEIXEIRA, W. Proterozoic accretionary belts of the Amazonian Craton. In: HATCHER Jr., R. D. et al. (Orgs.). The 4D Framework of Continental Crust. Boulder: Geological Society of America, 2007. p. 297-320. (Memoir, 200).

CPRM - SERVIÇO GEOLÓGICO DO BRASIL. Projeto Aerogeofísico Sudeste de Rondônia: relatório final de levantamento e processamento dos dados magnetométricos e gamaespectrométricos. Rio de Janeiro: Lasa Engenharia e Prospecções; Prospectors Aerolevantamentos e Sistemas, 2006. 27 v.

GUNN, P. J.; MAIDMENT, D.; MILLIGAN, P. R. Interpreting aeromagnetic data in areas of limited outcorps. Journal of Australian Geology and Geophysics, v. 17, n. 2, p. 175-185, 1997.

GUNN, P. J. et al. Geophysical mapping using the national airborne and gravity datasets: an example focusing on Broken Hill. Journal of Australian Geology and Geophysics, v. 17, n. 2, p. 127-136, 1997.

ISLES, D. J.; RANKIN, L. R. Geological interpretation of aeromagnetic data. Perth: The Australian Society of Exploration Geophysicists, 2013. 357 p.

JAQUES, A. L. et al. High resolution geophysics in modern geological mapping. Journal of Australian Geology and Geophysics, v. 17, n. 2, p. 159-173, 1997.

KROONENBERG, S. B. A Grenvillian granulite belt in the Colombian Andes and its relation to the Guiana Shield. Geologie en Mijnbouw, v. 61, p. 325-333, 1982. 
LITHERLAND, M. et al. The geology and mineral resources of the bolivian precambrian shield. London: British Geological Survey, 1986. 153 p. (Overseas Memoir, 9).

LOEWY SL, CONNELLY JN AND DALZIEL IW. 2004. An orphaned basement block: the Arequipa-Antofalla Basement of the central Andean margin of South America. Geol Soc Am Bull 116: 171-187.

OLIVEIRA, C. E. S.; PRADO, E. M. G.; SILVA, G. F.; GRAÇA, M. C. Carta geofísicageológica do Bloco Sudeste, áreas Rondônia e Acre. Porto Velho: CPRM, 2015. il.,color. Escala 1:250.000. Projeto Províncias Metalogenéticas do Brasil: áreas Rondônia e Acre. No prelo.

PIMENTEL, M.; FUCK, R. A. Neoproterozoic crustal accretion in Central Brazil. Geology, v. 20, n. 4, p. 375-379, 1992.

PRIEM, H.N.A. et al. Rb-Sr chronology of precambrian crustal evolution in Rondonia (western margin Brazilian Craton). Journal of South American Earth Sciences, v. 2, p. 163-170, 1989.

QUADROS, M. L. do E. S.; RIZZOTTO, G. J. (Orgs.). Geologia e recursos minerais do Estado de Rondônia: texto explicativo do mapa geológico e de recursos minerais do Estado de Rondônia. Escala 1:1.000.000. Porto Velho: CPRM, 2007. 116 p. il. Programa Geologia do Brasil.

RIZZOTTO, G. J. (Org.). Geologia e recursos minerais da folha Pimenteiras SD.20-X-D: texto explicativo do mapa geológico e de recursos minerais da folha Pimenteiras. Porto Velho: CPRM, 2010. 136 p. Programa Cartografia da Amazônia. Levantamentos Geológicos Básicos. Projeto Guaporé. Programa Geologia do Brasil.

RIZZOTTO, G. J. (Org.). Geologia e recursos minerais da Folha Vilhena (SD.20-X-B): Sistema de Informações Geográficas-SIG: texto explicativo do mapa geológico e de recursos minerais da folha Vilhena, escala 1:250.000. Porto Velho: CPRM, 2014. 175 p. il., color. Programa Geologia do Brasil (PGB).

RIZZOTTO, G. J. Petrologia e geocronologia do Complexo Máfico-ultramáfico Trincheira, sudoeste do Cráton Amazônico: implicações tectônicas do mesoproterozóico. 2012. 193 p. Tese (Doutorado em Ciências)-Instituto de Geociências, Universidade Federal do Rio Grande do Sul, Porto Alegre, 2012.

RIZZOTTO, G.J.; DEHLER, N.M., Arcabouço Estrutural da Faixa Alto Guaporé e o Regime Tectônico do Ectasiano na borda SW do Craton Amazônico. XI Simpósio Nacional de Estudos Tectônicos - V International Symposium on Tectonics of the SBG, Natal, p.130-132. 2007. 
RIZZOTTO, G. J.; HARTMANN, L. A. Geological and geochemical evolution of the Trincheira Complex, a mesoproterozoic ophiolite in the southwestern Amazon Craton, Brazil. Lithos, v. 148, n. 1, p. 277-295, 2012.

RIZZOTTO, G. J. et al. Geologia e Geocronologia da Suíte Metamórfica Colorado e suas encaixantes, SE de Rondônia: implicações para a evolução mesoproterozóica do Craton Amazônico. GEOLOGIA USP, Série Científica, v. 2, p. 41-56, 2002.

RIZZOTTO, G. J. et al. The Mesoproterozoic Guaporé suture in the SW Amazonian Craton: geotectonic implications based on field geology, zircon geochronology and $\mathrm{Nd}-\mathrm{Sr}$ isotope geochemistry. Journal of South American Earth Sciences, v.48, p. 271-295, 2013.

ROMANINI, S.J., Geologia e prospecção geoquímica/aluvionar da área Corumbiara/Chupinguaia-Rondônia. Porto Alegre: CPRM (Informe de Recursos Minerais. Série Metais do Grupo da Platina e Associados, 06). 2000.

RUIZ, A. S. Evolução geológica do sudoeste do Cráton Amazônico, região limítrofe Brasil-Bolívia, Mato Grosso. 2005. 260 p. Tese (Doutorado)-Universidade Estadual Paulista, Rio Claro, 2005.

SANTOS, J. O. S. et al. A new understanding of the provinces of the Amazon Craton based on integration of field mapping and $\mathrm{U}-\mathrm{Pb}$ and $\mathrm{Sm}-\mathrm{Nd}$ geochronology. Gondwana Research, v. 3, n. 4, p. 453-488, 2000.

SANTOS J. O. S. et al. Age and autochthonous evolution of the Sunsás orogen in West Amazon Craton based on mapping and U-Pb geochronology. Precambrian Research, v. 165, p. 120-152, 2008.

SCANDOLARA, J. E. (Org.). Geologia e recursos minerais do Estado de Rondônia: texto explicativo e mapa geológico do Estado de Rondônia. Brasília: CPRM, 1999. 97 p.

SCANDOLARA, J. E. A evolução proterozóica de Rondônia, principais eventos e cronologia dos movimentos tectônicos. In: SIMPÓSIO DE GEOLOGIA DA AMAZÔNIA, 6., 1999, Manaus. Boletim de Resumos Expandidos. Manaus: SBG-Núcleo Norte, 1999. p. 255258.

SCANDOLARA, J. E. et al. Mapa geológico do Estado de Rondônia. Escala 1:1.000.000. Porto Velho: CPRM, 1999.

SCANDOLARA, J. E. Geologia e evolução do terreno Jamari, embasamento da faixa Sunsás/Aguapeí, centro-leste de Rondônia, sudoeste do Cráton Amazônico. 2006. 383 p. Tese (Doutorado)-Instituto de Geociências, Universidade de Brasília, Brasília, 2006. 
SCHOBBENHAUS, C., 2001. Geological map of South America, scale 1:500000, CGMWCPRM-DNPM-UNESCO, Brasília, Brazil

\section{TASSINARI, C. C. G. Evolução geotectônica da Província Rio Negro-Juruena na Região}

Amazônica. 1981. 99 p. Dissertação (Mestrado em Geociências)-Instituto de Geociências, Universidade de São Paulo, São Paulo, 1981.

TASSINARI, C. C. G.; MACAMBIRA, M. J. B. Geochronological provinces of the Amazonian Craton. Episodes, v. 22, n. 3, p. 174-182, 1999.

TASSINARI, C. C. G.; SIGA Jr., O.; TEIXEIRA, W. Épocas metalogenéticas relacionadas à granitogênese do Cráton Amazônico. In: CONGRESSO BRASILEIRO DE GEOLOGIA, 33., 1984, Rio de Janeiro. Anais... Rio de Janeiro: SBG-Núcleo Rio de Janeiro, 1984. v.6, p. 2963-2977.

TASSINARI, C. C. G. et al. Geochronological systematics on basement rocks from the Rio Negro-Juruena Province (Amazonian Craton) and tectonic implications. International Geology Review, n. 38, p. 161-175, 1996.

TASSINARI, C. C. G. et al. The Amazonian Craton. In: CORDANI, U. G. (Ed.) et al. Tectonic evolution of South America. Rio de Janeiro: 31 st International Geological Congress, 2000. p. 41-95.

TEIXEIRA, W.; TASSINARI, C. C. G. Caracterização geocronológica da Província Rondoniana e suas implicações geotectônicas. In: SYMPOSIUM AMAZONICO, 2., 1984, Manaus. Anais. Brasília: DNPM, 1984. p. 89-101.

TEIXEIRA, W. et al. A review of the geochronology of the Amazonian Craton: tectonic implications. Precambrian Research, v. 42, p. 213-227, 1989.

TEIXEIRA, W. et al. A review of the tectonic evolution of the Sunsás belt, SW portion of the Amazonian Craton. Journal of South American Earth Science, v. 29, p. 47-60, 2010. 